University of Nebraska - Lincoln

DigitalCommons@University of Nebraska - Lincoln

USDA Forest Service / UNL Faculty Publications U.S. Department of Agriculture: Forest Service -National Agroforestry Center

2009

\title{
Mapping snags and understory shrubs for a LiDAR-based assessment of wildlife habitat suitability
}

\author{
Sebastián Martinuzzi \\ University of Idaho, smartinuzzi@vandals.uidaho.edu \\ Lee A. Vierling \\ University of Idaho, leev@uidaho.edu \\ William A. Gould \\ International Institute of Tropical Forestry GIS and Remote Sensing Laboratory,wgould@fs.fed.us \\ Michael J. Falkowski \\ Michigan Technological University, mjfalkow@mtu.edu \\ Jeffrey S. Evans \\ The Nature Conservancy, jeffrey_evans@tnc.org \\ See next page for additional authors
}

Follow this and additional works at: https://digitalcommons.unl.edu/usdafsfacpub

Martinuzzi, Sebastián; Vierling, Lee A.; Gould, William A.; Falkowski, Michael J.; Evans, Jeffrey S.; Hudak, Andrew T.; and Vierling, Kerri T., "Mapping snags and understory shrubs for a LiDAR-based assessment of wildlife habitat suitability" (2009). USDA Forest Service / UNL Faculty Publications. 213.

https://digitalcommons.unl.edu/usdafsfacpub/213

This Article is brought to you for free and open access by the U.S. Department of Agriculture: Forest Service -National Agroforestry Center at DigitalCommons@University of Nebraska - Lincoln. It has been accepted for inclusion in USDA Forest Service / UNL Faculty Publications by an authorized administrator of DigitalCommons@University of Nebraska - Lincoln. 


\section{Authors}

Sebastián Martinuzzi, Lee A. Vierling, William A. Gould, Michael J. Falkowski, Jeffrey S. Evans, Andrew T. Hudak, and Kerri T. Vierling 


\title{
Mapping snags and understory shrubs for a LiDAR-based assessment of wildlife habitat suitability
}

\author{
Sebastián Martinuzzi ${ }^{\text {a,* }}$, Lee A. Vierling ${ }^{a}$, William A. Gould ${ }^{\text {b }}$, Michael J. Falkowski ${ }^{\text {c }}$, Jeffrey S. Evans ${ }^{\mathrm{d}}$, \\ Andrew T. Hudak ${ }^{e}$, Kerri T. Vierling ${ }^{f}$
}

a Geospatial Laboratory of Environmental Dynamics, Department of Rangeland Ecology and Management, University of Idaho, Moscow, ID 83844, United States

b USDA Forest Service, International Institute of Tropical Forestry, Rio Piedras, PR 00926, United States

c School of Forest Resources and Environmental Science, Michigan Technological University, Houghton, MI 49931, United States

d The Nature Conservancy, Rocky Mountain Conservation Region, Fort Collins, CO 80534, United States

e USDA Forest Service, Rocky Mountain Research Station, Moscow, ID 83843, United States

${ }^{\mathrm{f}}$ Department of Fish and Wildlife Resources, University of Idaho, Moscow, ID 83844, United States

\section{A R T I C L E I N F O}

\section{Article history:}

Received 25 February 2009

Received in revised form 24 June 2009

Accepted 2 July 2009

\section{Keywords:}

LiDAR metrics

Wildlife habitat

Woodpeckers

Keystone structures

Species distribution modeling

Forest structure

\begin{abstract}
A B S T R A C T
The lack of maps depicting forest three-dimensional structure, particularly as pertaining to snags and understory shrub species distribution, is a major limitation for managing wildlife habitat in forests. Developing new techniques to remotely map snags and understory shrubs is therefore an important need. To address this, we first evaluated the use of LiDAR data for mapping the presence/absence of understory shrub species and different snag diameter classes important for birds (i.e. $\geq 15 \mathrm{~cm}, \geq 25 \mathrm{~cm}$ and $\geq 30 \mathrm{~cm}$ ) in a 30,000 ha mixed-conifer forest in Northern Idaho (USA). We used forest inventory plots, LiDAR-derived metrics, and the Random Forest algorithm to achieve classification accuracies of $83 \%$ for the understory shrubs and $86 \%$ to $88 \%$ for the different snag diameter classes. Second, we evaluated the use of LiDAR data for mapping wildlife habitat suitability using four avian species (one flycatcher and three woodpeckers) as case studies. For this, we integrated LiDAR-derived products of forest structure with available models of habitat suitability to derive a variety of species-habitat associations (and therefore habitat suitability patterns) across the study area. We found that the value of LiDAR resided in the ability to quantify 1) ecological variables that are known to influence the distribution of understory vegetation and snags, such as canopy cover, topography, and forest succession, and 2) direct structural metrics that indicate or suggest the presence of shrubs and snags, such as the percent of vegetation returns in the lower strata of the canopy (for the shrubs) and the vertical heterogeneity of the forest canopy (for the snags). When applied to wildlife habitat assessment, these new LiDAR-based maps refined habitat predictions in ways not previously attainable using other remote sensing technologies. This study highlights new value of LiDAR in characterizing key forest structure components important for wildlife, and warrants further applications to other forested environments and wildlife species.
\end{abstract}

(c) 2009 Elsevier Inc. All rights reserved.

\section{Introduction}

The lack of spatially explicit data about forest three-dimensional structure is a major challenge for managing biodiversity and wildlife habitat (Russell et al., 2007; Venier \& Pearce, 2007). Such information is important because characteristics associated with the structure of forests (e.g. height of the trees, presence or absence of understory, canopy closure, tree diameter, abundance and size of dead trees, etc.) are important factors explaining 1 ) the presence of many wildlife species, 2) the functional use of the habitat (e.g. nesting, foraging,

\footnotetext{
* Corresponding author. Tel.: +1 2088854946.

E-mail address: smartinuzzi@vandals.uidaho.edu (S. Martinuzzi).
}

cover, roosting), and 3) the overall diversity of wildlife species in forests (Brokaw \& Lent, 1999; Davis, 1983; MacArthur \& MacArthur, 1961). During the last two decades, passive remote sensing data have been used to characterize successfully different aspects of forested habitats over broad areas, but have been typically unable to describe three-dimensional (3-D) structural characteristics (see reviews by Kerr \& Ostrovsky, 2003; McDermid et al., 2005; Wulder \& Franklin, 2003). As a result, it is necessary to develop novel ways to characterize forest structure, with a special emphasis on those aspects that are relevant to wildlife habitat and biodiversity.

LiDAR remote sensing can be used to measure directly the 3-D structure of terrestrial and aquatic ecosystems across broad spatial extents (Lefsky et al., 2002). LiDAR data, in conjunction with various sources of ancillary data, have been used to quantify successfully different aspects of forest 3-D structure, such as biomass, canopy cover 
and height, canopy height profiles, successional stages, as well as subcanopy topography (Clawges et al., 2007; Drake et al., 2002; Falkowski et al., 2009; Harding et al., 2001; Hofton et al., 2002; Hudak et al., 2006, 2008a; Nelson et al., 1988). These data have been recently incorporated into assessments of biodiversity (Clawges et al., 2008; Goetz et al., 2007) and wildlife habitat modeling (see Vierling et al., 2008 for a review). However, the mapping of certain habitat characteristics requires more research. For instance, little is known about the capability of LiDAR data for mapping the distribution of snags (i.e. standing dead trees) and understory shrub species, two critical components of wildlife habitat in forests (Davis, 1983; Hagar, 2007; Thomas et al., 1979) and indicators of forest biodiversity and ecosystem health (Kerns \& Ohmann, 2004; Noss, 1999; Sampson \& Adams, 1994).

This study advances the application of LiDAR remote sensing for mapping forest structure and wildlife habitat. Our objective was to evaluate the use of LiDAR data to map 1) the distribution of understory shrubs and snags, and 2) habitat suitability patterns for different wildlife species known to be dependent upon these habitat resources. This study was focused on Moscow Mountain, a mixedconifer forest located in the Inland Northwest (US) that has previously served as a suitable testbed for numerous LiDAR applications (Evans \& Hudak, 2007; Falkowski et al., 2009; Hudak et al., 2006, 2008a,b).

\subsection{Background and rationale}

Mapping the distribution of snags and understory shrub species across the landscape presents major challenges. Recent studies using LiDAR data have been able to characterize height and/or cover of the understory vegetation, where understory is represented by all the woody vegetation in the strata (i.e. shrubs and trees), or suppressed trees only (e.g. Goodwin, 2006; Hill \& Broughton, 2009; Maltamo et al., 2005; Skowronski et al., 2007; Riaño et al., 2003). This work was done through the use of canopy height thresholds, cluster analysis and visual interpretation. The studies have shown, however, that assessments of understory vegetation with LIDAR are typically less accurate under dense tree canopies (e.g. Goodwin, 2006; Maltamo et al., 2005; Skowronski et al., 2007; Su \& Bork, 2007), where the proportion of laser pulses reaching the lower forest strata decreases. Maps of understory shrub distribution should be reliable under different forest density conditions so that spatially consistent ecological inferences can be made. In this sense, Hill and Broughton (2009) showed that it is possible to characterize understory vegetation in closed forests, by integrating leaf-on and leaf-off LiDAR data. This approach, however, requires 1) a forest dominated by deciduous trees, and 2) the availability of multiple LiDAR acquisitions over the same area. In addition, animal use of different understory vegetation components does vary. In the coniferous forests of the Pacific Northwest (US), for example, distinguishing deciduous shrubs from conifer saplings is vital for evaluating certain types of wildlife habitats, as these components have different ecological function (see Hagar, 2007). A recent study conducted in an Aspen parkland in Canada, however, found no relationship $(p>0.05)$ between the structure of the understory (true) shrub community and the LiDAR reference data (Su \& Bork, 2007). With regard to snags, Bater et al. (2007) were able to relate the structural heterogeneity of forest stands from LiDAR with proportions of trees in different stages of decay; in a conifer-dominated coastal forest of British Columbia, Canada. The study indicated that more research is required to test this approach in other forest environments. In addition, it is important in many wildlife habitat applications to understand not only the spatial distribution of snags, but also their size (e.g. larger animal species typically use larger snag diameters than smaller species). In this sense, a previous effort predicting the volume of standing dead wood material from LiDARderived canopy metrics achieved poor results (RMSE 79\%) (Pesonen et al., 2008).

A variety of environmental factors can influence the presence of snags and understory shrubs in forests, and therefore have the potential to serve as predictor variables in a distribution modeling approach. Studies evaluating the structure and composition of understory vegetation found that overstory canopy structure, topography and land use can all influence the presence of understory shrub cover in forests (Bartemucci et al., 2006; Gracia et al., 2007; Kerns \& Ohmann, 2004; Kilina et al., 1996; McKenzie \& Halpern, 1999; Van Pelt \& Franklin, 2000), with overstory density being, frequently, the most important variable. Understory vegetation is consistently denser in open forests, where more light can reach the ground; but it is more variable and less predictable in closed forests (Bartemucci et al., 2006).

The abundance and size of snags, on the other hand, is a result of the combined processes of forest succession, natural snag dynamics, forest management practices, and episodic disturbance events (Cline et al., 1980; Flanagan et al., 2002; Kennedy et al., 2008; Korol et al., 2002; Ohmann et al., 1994). Older forest stands typically support larger snags than do younger stands. In mountainous regions, topographic positions (i.e. slopes and aspects) exposed to more severe weather conditions tend to support higher abundance of snags (Flanagan et al., 2002). At the same time, managed forest stands have typically fewer larger snags than non-managed stands (Kennedy et al., 2008; Korol et al., 2002). Episodic disturbance events such as drought, snow, ice, fire or insect outbreaks can also increase the number of snags locally (Morrison \& Raphael, 1993). A previous study modeling snag density with Landsat and geoclimatic data showed modest results, with only half of the predictions falling within a $15 \%$ deviation from the field validation values (Frescino et al., 2001). On the other hand, Bater et al. (2007) found that the coefficient of variation of the LiDAR height data was a strong predictor of the proportion of trees in different stages of decay at the stand level $(r=0.85, p<0.001$, RMSE $=4.9 \%$ ). We are unaware of efforts to model the presence of snags of different sizes.

LiDAR data can be utilized to derive a variety of environmental factors known to explain the presence of understory vegetation and snags, including canopy structure (e.g. Hudak et al., 2008a,b), forest successional stage (e.g. Falkowski et al., 2009), and topography (e.g. Hudak et al., 2008a,b). Coupled with the fact that laser pulses can also interact directly with understory vegetation and dead trees, the use of LiDAR data should provide a way to advance the mapping of understory shrub and snag distributions in forested environments. In addition, while previous efforts assessing wildlife habitat with LiDAR have been focused from an inductive perspective, that is, by allowing the canopy metrics explain the variation in some type of field animal data (such as abundance, reproductive success, and richness) (e.g. Broughton et al., 2006; Clawges et al., 2008; Goetz et al., 2007; Graf et al., 2009; Hinsley et al., 2002, 2008), few studies have assessed wildlife habitats from a deductive perspective, that is, through the mapping of known, key species-habitat features (Hyde et al., 2006; Nelson et al., 2005; Swatantran et al., 2008).

Habitat suitability models or indices (a.k.a. HSIs) are common tools used by researchers and managers with the objective of assessing the potential of an area to support the resource, shelter and reproductive needs for given wildlife species (Edenius \& Mikusiński, 2006; Turner et al., 2001). These models quantify species-habitat relationships based on empirical data and literature review on limiting resources, with values that range between 0.0 (unsuitable habitat) and 1.0 (optimum habitat). For the United States, a large number of habitat suitability models are available through the US Fish and Wildlife Service (USFWS) and individual efforts. Edenius and Mikusiński (2006) provide a comprehensive description of HSI worldwide sources and applications.

The spatial output of HSIs is a map depicting habitat suitability values across the landscape, for the target species. In this sense, Nelson et al. (2005) used LiDAR to identify forest patches with more than $20 \mathrm{~m}$ in height, which are known to be suitable for the endangered Delmarva fox squirrel (Sciurus niger cinereus). This assessment, however, recognized the lack of spatial data about understory 
vegetation, which is a complementary variable explaining the distribution of the species (Nelson et al., 2005). In California, Hyde et al. (2005, 2006) used LiDAR data to map forest biomass, canopy cover and height at the landscape scale, with the expectation that these products will be helpful to assess habitat suitability for the California spotted owls. Finally, Swatantran et al. (2008) combined forest structural data from LiDAR with maps of stressed and dead vegetation from a hyperspectral sensor, to map potential habitats for the Ivory-billed woodpecker (Campephilus principalis). Here, we use known information about species-habitat preferences to map habitat suitability. Our study includes 1) multiple species from a different wildlife group (i.e. avian), and 2) the use and development of additional habitat variables of forest structure relative to previous studies.

\section{Methods}

\subsection{Study area}

Moscow Mountain comprises about 30,000-ha of managed, mixed temperate coniferous forest in Northern Idaho (Latitude $46^{\circ} 44^{\prime} \mathrm{N}$, Longitude $116^{\circ} 58^{\prime} \mathrm{W}$ ) (Falkowski et al., 2005). The area is topographically complex. Common tree species include ponderosa pine (Pinus ponderosa), Douglas fir (Pseudotsuga menziesii), grand fir (Abies grandis), western red cedar (Thuja plicata), and western larch (Larix occidentalis). Shrub species include Ocean Spray (Holodiscus discolor), Ninebark (Physocarpus malvaceus), Common snowberry (Symphoricarpos albus), Spiraea (Spiraea betulifolia), Huckleberry (Vaccinium membranaceum), and Mountain Maple (Acer galbrum) (Falkowski et al., 2005). Forest species composition varies with temperate/moisture gradient (Cooper et al., 1991). Private industrial forest companies manage most of the area for timber, but a large tract of experimental forest is also owned and managed by the University of Idaho for research purposes. The city of Troy, ID manages a watershed. Private landowners manage many land parcels, and there is a small tract of old growth forest protected as a county park. All these factors contribute to the structural and compositional complexity found in the Moscow Mountain forests. Approximately $83 \%$ of the study area is covered by forest in different stages of succession (Falkowski et al., 2009). Young and mature forests cover $65 \%$ of the total area; stand initiation (i.e. growing space reoccupied by seedlings, saplings, or shrubs following stand replacing disturbance) represents 10\%; understory reinitiation (i.e. older cohort of trees being replaced by new individuals) represents $7 \%$, and old growth forest $1 \%$. The remaining $17 \%$ correspond to non-forest, open areas of grasses or weeds (Falkowski et al., 2009).

\subsection{Target wildlife species}

To apply our work to wildlife habitat, we selected four bird species that inhabit Moscow Mountain (Scott et al., 2002), including the dusky flycatcher (Empidonax oberholseri), hairy woodpecker (Picoides villosus), Lewis's woodpecker (Melanerpes lewis), and downy woodpecker (Picoides pubescens), and made use of the published habitat suitability models available for these species (i.e. Roloff, 2001; Schroeder, 1982; Souza, 1982, 1987). The habitat requirements of these species comprise a broad range of forest structural variables including but not limited to snags and understory shrubs, making these species ideal for evaluating the potential of mapping habitat suitability from LiDAR data (Table 1). Furthermore, woodpecker species have been found to be indicators of overall forest bird diversity (Virkkala, 2006).

\subsection{Definition of understory shrub and snag classes}

We considered understory shrubs to be present if they covered more than $25 \%$ in a $20 \mathrm{~m}$ by $20 \mathrm{~m}$ pixel. This definition was based on land cover mapping standards and the species HSIs. A 25\% threshold cover per pixel was established by the Multi-Resolution Land
Table 1

Target avian species and habitat characteristics, based on the corresponding habitat suitability models (i.e. Roloff, 2001; Schroeder, 1982; Souza, 1982, 1987).

\begin{tabular}{|c|c|c|}
\hline Species name & $\begin{array}{l}\text { Habitat variables and } \\
\text { corresponding life requisite }\end{array}$ & $\begin{array}{l}\text { Optimum habitat } \\
\text { (i.e. } \mathrm{HSI}=1.0 \text { ) }\end{array}$ \\
\hline $\begin{array}{l}\text { Dusky } \\
\text { flycatcher }\end{array}$ & $\begin{array}{l}\text { Percent tree canopy cover } \\
\text { (nesting and foraging) } \\
\text { Understory shrub cover } \\
\text { (nesting and foraging) }\end{array}$ & $\begin{array}{l}\text { Open forested conditions with } \\
\text { a well-developed understory } \\
\text { shrub cover }\end{array}$ \\
\hline $\begin{array}{l}\text { Hairy } \\
\text { woodpecker }\end{array}$ & $\begin{array}{l}\text { Number of snags } \geq 25 \mathrm{~cm} \\
\text { diameter per ha (nesting) } \\
\text { Mean diameter of overstory } \\
\text { trees (cover and nesting) } \\
\text { Percent tree canopy cover } \\
\text { (cover) }\end{array}$ & $\begin{array}{l}\text { Mature forest stands with } \\
\text { moderate tree canopy cover } \\
\text { and at least } 5 \text { snags } \geq 25 \mathrm{~cm} \\
\text { diameter per ha. }\end{array}$ \\
\hline $\begin{array}{l}\text { Lewis's } \\
\text { woodpecker }\end{array}$ & $\begin{array}{l}\text { Percent tree canopy cover } \\
\text { (summer food) } \\
\text { Understory shrub cover } \\
\text { (summer food) } \\
\text { Number of snags } \geq 30 \mathrm{~cm} \\
\text { diameter per ha (nesting) }\end{array}$ & $\begin{array}{l}\text { Open forested conditions with } \\
\text { a well-developed understory } \\
\text { shrub cover and at least } \\
2.5 \text { snags } \geq 30 \mathrm{~cm} \text { diameter } \\
\text { per ha. }\end{array}$ \\
\hline $\begin{array}{l}\text { Downy } \\
\text { woodpecker }\end{array}$ & $\begin{array}{l}\text { Basal area (food) } \\
\text { Number of snags } \geq 15 \mathrm{~cm} \\
\text { diameter per ha (nesting) }\end{array}$ & $\begin{array}{l}\text { Forest stands with low basal } \\
\text { area and more than } 13 \text { snags } \\
\geq 15 \mathrm{~cm} \text { diameter per ha. }\end{array}$ \\
\hline
\end{tabular}

Characteristics Consortium to define the class "shrubland" in the 1992 (US) National Land Cover map. At the same time, the habitat suitability for the species that use understory was low or zero when shrub cover was less than $25 \%$. For the purposes of our study, the understory shrub class is comprised of true shrub species only, and did not include saplings that can be common in the understory. The reason for this resides in the ecological function that non-coniferous vegetation has in Pacific Northwest conifer forests, as described by Hagar (2007). In this region, non-coniferous vegetation determines the abundance and distribution of many vertebrates, providing the foundation for food webs through direct and indirect food resources (i.e., broad-leaf forage, fruits, flowers, and insects) that are not provided by conifers (Hagar, 2007). This is the case of the Lewis's woodpecker and the dusky flycatcher, which use the understory shrub layer as a food source of insects (see Table 1). The dusky flycatcher uses the understory shrub layer also for nesting, and studies in Idaho have found that nesting occurs exclusively in non-coniferous plants (i.e. in true shrubs) (Kroll \& Haufle, 2006).

We focused our attention on the snag diameters that are used by the woodpecker species of this study, based on their specific HSIs. According to these models, the snag diameters (at breast height, or DBH) are $\geq 15 \mathrm{~cm}$ for the Downy woodpecker (Schroeder, 1982), $\geq 25 \mathrm{~cm}$ for the Hairy woodpecker (Souza, 1987), and $\geq 30 \mathrm{~cm}$ for the Lewis's woodpecker (Souza, 1982) (Table 1). We use the term "classes", "ranges", or "categories" indistinctively to refer to these snag diameters.

\subsection{Field data acquisition and interpretation}

We utilized forest inventory plots and LiDAR data that have been acquired by previous efforts to characterize various aspects of forest structure in the region (Evans \& Hudak, 2007; Falkowski et al., 2005, 2009; Hudak et al., 2006, 2008a,b). These plots contain a variety of snag and understory shrub densities, and thus were suitable for this study. The use of standard forest inventory plots should facilitate the application of the findings of this study to other areas, as well as the evaluation of limitations of such data sets for wildlife habitat assessments.

Eighty-three, $405 \mathrm{~m}^{2}$ fixed-radius ( $11.35 \mathrm{~m}$ radius) forest inventory plots were located across the study area in 2003 by Falkowski et al. (2005), using a stratified random sampling protocol designed to capture the full range of canopy structure conditions and forest species composition. Information in each plot included the number and diameter (i.e., DBH) of dead trees, and the percentage of (true) shrub 
cover, among other standard forest inventory data. All trees (live or dead) with diameter $>2.7 \mathrm{~cm}$ were measured. Within each plot, visual estimates of true shrub cover were obtained in 4 subplots ( $4 \mathrm{~m}$ by $4 \mathrm{~m}$ in size), using a reference schema of 12 canopy cover classes that ranges from 0\% to 95-100\% (see Falkowski et al., 2005). The percentage of shrub cover for each plot was obtained by averaging the estimates of the smaller subplots. More information about the field data used in this study can be obtained in Falkowski et al. (2005).

Understory shrubs were present (i.e. $>25 \%$ cover) in 48 of the 83 plots. The median shrub cover for those 48 plots was $53 \%$ (Table 2). The height of the shrubs observed in the individual subplots $(N=83 \times 4=332)$ was typically below $2 \mathrm{~m}$ ( $80 \%$ of the cases). In addition, there were 177 snags in the sampled population, with a diameter ranging from $12.7 \mathrm{~cm}$ to $97.0 \mathrm{~cm}$. and with small snags greatly outnumbering larger snags (Fig. 1). Within those, there were 151 snags with $\mathrm{DBH} \geq 15 \mathrm{~cm}, 73$ snags with $\mathrm{DBH} \geq 25 \mathrm{~cm}$, and 46 snags with $\mathrm{DBH} \geq 30 \mathrm{~cm}$. Snags were common as they appeared in about $55 \%$ of the plots. Eighty five percent of the snags sampled were smaller than $40 \mathrm{~cm}$ in diameter. Comparable snag diameters and a skewed class distribution have been found in other managed conifer forests (Ganey, 1999; Spiering \& Knight, 2005). The median snag density of the Moscow Mountain plots was 1 snag per plot. Expressed at the ha-scale, this is equivalent to 25 snags/ha, which is close to the 32 snags/ha found in a comparable area (Spiering \& Knight, 2005). For those plots in which snags were present, the snags $\geq 15 \mathrm{~cm}$ and $\geq 25 \mathrm{~cm}$ appeared with a median density of 2 snags per plot, and the snags $\geq 30 \mathrm{~cm}$ with a median density of 1 snag per plot. In addition, the presence of snags differed depending upon the successional stage of the plot (Table 3 ).

\subsection{LiDAR data acquisition and preprocessing}

We used LiDAR-derived metrics developed by previous studies, which have proved useful for mapping and predicting different attributes of forest structure (see Falkowski et al., 2009; Hudak et al., 2006, 2008a,b). Discrete, multiple return LiDAR data (1.95 m nominal post spacing) was acquired by Horizons, Inc., in the summer of 2003, using an ALS40 system operating at a wavelength of $1064 \mathrm{~nm}$ and flown at approximately $2500 \mathrm{~m}$ elevation. LiDAR data were first separated into ground and non-ground returns using the Multi-scale Curvature Classification algorithm by Evans and Hudak (2007). Thirty four LiDAR-based metrics, consisting of 19 canopy height metrics and 15 topographic metrics, were then calculated at the plot scale (Falkowski et al., 2009; Hudak et al., 2008a) (Table 4). This was done by clipping the row LiDAR data using the plot extent. LiDAR metrics were also calculated for the entire area at a spatial grid resolution of $20 \mathrm{~m}$, which corresponded to the dimensions of the field plots (Hudak et al., 2008a). We used these metrics as predictor variables for mapping snags and understory shrubs. We also utilized auxiliary, LiDAR-derived products developed in previous studies. This included a map of basal area (BA) by Hudak et al. (2008a) (accuracy $=98 \%$ ), and a map of six forest successional stages by Falkowski et al. (2009) (accuracy $=95 \%$ ).

\subsection{Classification tool}

For mapping snag and understory shrub distribution we used the Random Forest (RF) algorithm (Breiman, 2001), a novel and powerful

Table 2

Understory shrub cover characteristics.

\begin{tabular}{lllllll}
\hline Understory shrub cover & \# of plots & \multicolumn{3}{l}{ \% cover, when present } \\
\cline { 2 - 6 } & & Mean & St. dev. & Min. & Max. & Median \\
\hline Present (i.e. $>25 \%$ cover) & 48 & 54.0 & 18.7 & 25.8 & 100.0 & 52.5 \\
Absent (i.e. $\leq 25 \%$ cover) & 35 & & & & & \\
\hline
\end{tabular}

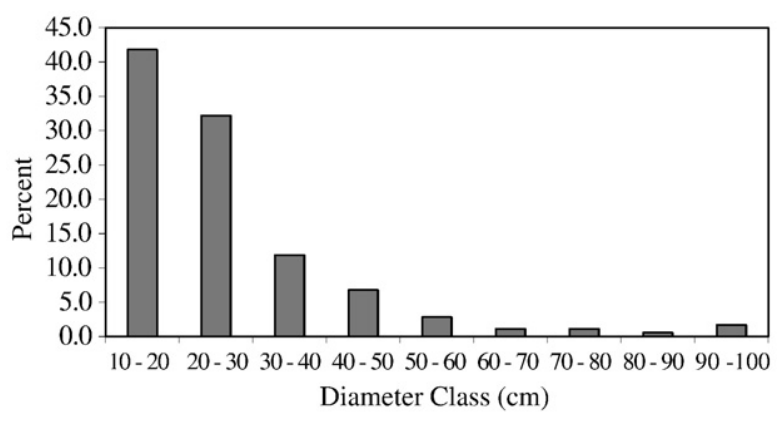

Fig. 1. Snag distribution based on diameter.

extension of classification tree techniques that has been shown to produce excellent results in classifications of remotely sensed and ecological data (Cutler et al., 2007; Lawrence et al., 2006; Prasad et al., 2006). Random Forest can handle complex interactions among predictor variables without making distributional assumptions and without overfitting (Breiman, 2001; Cutler et al., 2007; Lawrence et al., 2006). The RF algorithm develops classification rules by estimating a large number of trees (100s to >1000s; i.e., a forest), in which each classification tree is based on a random subset of the training data, and each classification tree split is based on a random subset of the predictor variables (Breiman, 2001). After the iterations, the predictions from the individual classification trees are combined using the rule of majority votes. Classification accuracies that result from this approach perform very well compared to other classifiers (Liaw \& Wiener, 2002). The RF algorithm provides a reliable internal estimate of classification accuracy using the portion of the data that is randomly withheld as each classification tree is developed (i.e., the out-of-bag sample [OOB], approximately $37 \%$ of the training data), which makes it unnecessary to have a separate accuracy assessment (Breiman, 2001; Lawrence et al., 2006; Prasad et al., 2006). In addition, the RF algorithm provides information about the importance of each predictor variable, by quantifying changes in classification error when the OOB data for that variable is altered. Hudak et al. (2008a,b) and Falkowski et al. (2009) found the RF algorithm to be practical for analyzing the field plot and LiDAR data used in this study.

We used the RF package (Liaw \& Wiener, 2002) in R (www.r-project. org; R Development Core Team, 2005). We added a model selection step using the model selection algorithm varSelRF (Díaz-Uriarte \& Alvarez, 2006), which is a RF-based tool available also in R. The varSelRF algorithm iteratively eliminates the least important variables (with importance as measured from $\mathrm{RF}$ ), resulting in a model with the smallest possible number of variables and whose error rate is within one standard error of the minimum error rate of all forests (Díaz-Uriarte, 2008). Our predictor variables (i.e. the LiDAR-derived metrics) were continuous, therefore avoiding potential bias in variable selection that can result from combining discrete and continuous predictors (see

Table 3

Snag distribution within forest successional stages.

\begin{tabular}{|c|c|c|c|c|c|c|c|c|}
\hline \multirow[t]{2}{*}{ Successional class } & \multirow[t]{2}{*}{ Area (ha) } & \multirow[t]{2}{*}{$(\%)$} & \multirow[t]{2}{*}{ Plots (\#) } & \multicolumn{5}{|c|}{$\begin{array}{l}\text { Proportion of plots with snags } \\
\text { of different diameter classes } \\
\text { (in } \mathrm{cm} \text { ) }\end{array}$} \\
\hline & & & & $\geq 15$ & $\geq 25$ & $\geq 30$ & $\geq 35$ & $\geq 50$ \\
\hline Open & 5426 & 17 & 9 & 0.00 & 0.00 & 0.00 & 0.00 & 0.00 \\
\hline Stand initiation & 3165 & 10 & 8 & 0.00 & 0.00 & 0.00 & 0.00 & 0.00 \\
\hline Understory reinitiation & 2073 & 7 & 6 & 0.50 & 0.50 & 0.33 & 0.17 & 0.17 \\
\hline Young multistory & 8727 & 28 & 34 & 0.53 & 0.41 & 0.32 & 0.12 & 0.06 \\
\hline Mature multistory & 11,673 & 37 & 26 & 0.81 & 0.62 & 0.50 & 0.35 & 0.15 \\
\hline Old multistory & 393 & 1 & NA & NA & NA & NA & NA & NA \\
\hline Total & 31,458 & 100 & 83 & & & & & \\
\hline
\end{tabular}

Inventory data was not available for old growth forest (only GPS locations). 
Table 4

LiDAR-derived metrics of canopy height (top group) and topography (bottom group).

\begin{tabular}{|c|c|c|c|c|c|}
\hline Metric name & Metric description & $\begin{array}{l}\text { Understory } \\
\text { shrubs }\end{array}$ & $\begin{array}{l}\text { Snags } \geq 15 \mathrm{~cm} \\
\text { diameter }\end{array}$ & $\begin{array}{l}\text { Snags } \geq 25 \mathrm{~cm} \\
\text { diameter }\end{array}$ & $\begin{array}{l}\text { Snags } \geq 30 \mathrm{~cm} \\
\text { diameter }\end{array}$ \\
\hline HMIN & Minimum height & & & & \\
\hline HMAX & Maximum height & & & $\mathrm{X}$ & $\mathrm{X}$ \\
\hline HSKEW & Skewness of heights & & & & \\
\hline HKURT & Kurtosis of heights & & & $\mathrm{X}$ & \\
\hline HMEAN & Mean height & & $\mathrm{X}$ & & \\
\hline HMAD & Median Absolute Deviation of Heights $1.4826^{*}$ median(abs $(\mathrm{x}$-median $(\mathrm{x}))$ ) & & $\mathrm{XX}$ & $\mathrm{XX}$ & $\mathrm{XX}$ \\
\hline HIQR & Heights interquartile range & & $\mathrm{X}$ & & \\
\hline H05PCT & Heights 5 th percentile & & & & \\
\hline H10PCT & Heights 10 th percentile & & & & \\
\hline Н25PCT & Heights 25 th percentile & & & & \\
\hline HMEDIAN & Median height & & & & $\mathrm{X}$ \\
\hline CANOPY & Canopy cover/density (vegetation returns/total returns*100) & & & & \\
\hline STRATUMO & Percentage of ground returns $=0 \mathrm{~m}$ & $\mathrm{X}$ & & & \\
\hline STRATUM1 & Percentage of non-ground returns $>0 \mathrm{~m}$ and $\leq 1 \mathrm{~m}$ & & & & \\
\hline STRATUM2 & Percentage of vegetation returns $>1 \mathrm{~m}$ and $\leq 2.5 \mathrm{~m}$ & $\mathrm{X}$ & & & \\
\hline STRATUM3 & Percentage of vegetation returns $>2.5 \mathrm{~m}$ and $\leq 10 \mathrm{~m}$ & & & & \\
\hline STRATUM4 & Percentage of vegetation returns $>10 \mathrm{~m}$ and $\leq 20 \mathrm{~m}$ & & & & $\mathrm{X}$ \\
\hline STRATUM5 & Percentage of vegetation returns $>20 \mathrm{~m}$ and $\leq 30 \mathrm{~m}$ & & & $\mathrm{X}$ & \\
\hline STRATUM6 & Percentage of vegetation returns $>30 \mathrm{~m}$ & & & & \\
\hline ELEV & Elevation (meters) & & & & \\
\hline SLP & Slope/area (wetness indicator) & & & & \\
\hline SLPPCT & Slope in \% & & & & \\
\hline ASPDEG & Aspect in degrees & & & & \\
\hline CURV & Curvature (Tarboton 1997) & & & $\mathrm{X}$ & \\
\hline EASTNESS & UTM easting $(\mathrm{m})$ & & & $\mathrm{X}$ & $\mathrm{X}$ \\
\hline NORTHNESS & UTM northing $(\mathrm{m})$ & & & & \\
\hline ERR & Elevation to relief ratio (Evans 1972) & & & $\mathrm{X}$ & \\
\hline SRR & Slope to relief ratio (Evans 1972) & & & & \\
\hline FLDIST & Flow distance to streams (Tarboton 1997) & & $\mathrm{X}$ & $\mathrm{X}$ & \\
\hline INVCTI & Compound topographic index (Moore et al., 1993) & & & $\mathrm{X}$ & $\mathrm{X}$ \\
\hline BOLSTAD & Bolstad's landform index (Bolstad and Lillesand 1992) & & & $\mathrm{X}$ & $\mathrm{XX}$ \\
\hline SSINA & Percent slope* $\sin ($ aspect) transformation (Stage 1976) & & & & \\
\hline SCOSA & Percent slope ${ }^{*} \cos$ (aspect) transformation (Stage 1976) & $\mathrm{X}$ & & & \\
\hline TRI & Topographic ruggedness index (Riley et al., 1999) & & $\mathrm{X}$ & & \\
\hline
\end{tabular}

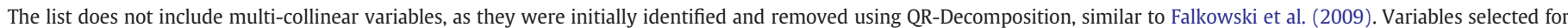

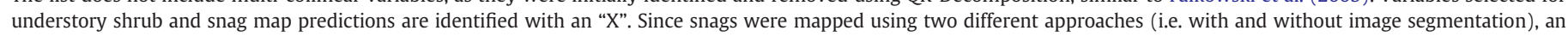
additional " $X$ " was added when the variable was selected in both methods.

Strobl et al., 2007). Our training data involved a random component, avoiding potential bias in accuracy assessments involving crossvalidation (Huang et al., 2003).

\subsection{Understory shrub and snag mapping with LiDAR - Modeling approach and evaluation}

We modeled the distribution (i.e. presence/absence) of understory shrubs and snags with RF, by applying the corresponding best model to the entire region. In addition, we modeled the distribution of snags using a segmentation-based approach. Data segmentation fragments the data into smaller, more homogeneous regions based on some ecological, spectral, or geographic attribute. This approach typically increases the quality of the final classification. We evaluated the consequences of segmenting the snag data based on forest succession, because succession is an important ecological variable influencing the presence and size of snags in forests, which we observed to be occurring in our study area as the abundance of snags differed among the different successional classes (see Table 3). As a result, we segmented the study area into three regions with distinctive snag abundances, including 1) an area composed by the open and stand initiation categories (OA\&SI), without snags; 2 ) an area composed by the young multistory and understory reinitiation (YMS\&UR) categories, with snags present but less than those observed in 3) the mature multistory (MMS) category. Finally, the MMS class was combined with the old growth forest (OF) (less than $1 \%$ of the study area) to form the third segmentation region (MMS\&OF). As a result, the three areas defined were: OA\&SI (without snags), and YMS\&UR and MMS\&OF (with snags present in different proportions).
Segmentation of our data reduced the amount of training data available for classification and the area to be classified (i.e. the target area), but maintained the overall relationship between training data/ target area, and therefore the representation of the field plots. For example, the area-wide ratio of training data/target area for Moscow Mountain was 0.83 (i.e. 83 plots $/ 100 \%$ of the study area), for the MMS\&OF area the ratio was 0.68 (i.e. 26 plots $/ 38 \%$ of Moscow Mountain) and for the YMS\&UR area the ratio was 1.14 (i.e. 40 plots/ $35 \%$ of Moscow Mountain). Fu et al. (2005) showed that the results from bootstrap cross-validations are reliable with small sample sizes (as small as 16). In summary, we modeled the distribution of the three different snag classes (i.e. $\geq 15 \mathrm{~cm}, \geq 25 \mathrm{~cm}$ and $\geq 30 \mathrm{~cm}$ ) using two approaches, one that included developing a single predictive model/ classification for the entire area, and another that resulted from a combination of different predictive models within three different areas (i.e. OA\&SI, YMS\&UR, and MMS\&OF). Since snags were absent in the OA\&SI, we did not model their distribution in this region. Finally, we compared the results of the final snag classifications with and without including the segmentation approach.

Previous to any presence/absence classification (for either shrubs or snags) with RF, we ensured that the input data were balanced. Studies have shown that severe imbalanced data sets (i.e., when the presence or absence classes constitute a very small minority of the data distribution) can pose significant drawbacks in the performance attainable by most machine learning classification systems, including RF (see Chen et al., 2004; Sun et al., 2007). The ratio between the number of samples for the minority class and the number of samples for the majority class constitutes the minority/majority ratio, ranging in values between 1 and $>0$. Unfortunately, there is not a universal 
ratio between minority and majority classes defining what constitutes an imbalanced vs. balanced data set. In practice, however, imbalanced data in presence/absence classifications typically include cases in which the minority class (whether presence or absence) represents $10 \%$ or less of the data, equivalent to a minority/majority class ratio $\leq 0.11$ (see Chen et al., 2004; Sun et al., 2007). In another study with RF, Ruiz-Gazen and Villa (2007) used a conservative $\leq 0.2$ class-ratio threshold to define the presence of imbalanced classes. In our data set, the minority/majority class ratios were much higher (i.e. closer to 1.00 ) than those reported by previous studies, indicating that the data were balanced and suitable for classification with RF (Table 5).

We ran the varSelRF algorithm several times for each classification, including 50 runs for those that were conducted in the entire area and 20 runs for those that were conducted in the smaller, segmented portions. Running the varSelRF several times allowed us to evaluate the potential presence of different candidate solutions. Each time, we incorporated the varSelRF solution model into the RF algorithm to evaluate the resulting misclassification error. If different candidate solutions were present, we selected the final model based on the criteria of smallest total and within class errors and smaller number of variables. The final predictive distribution models were applied across the region using the AsciiGridPredict command in the yalmpute package (Crookston \& Finley, 2008) available in the R software package. We ran the RF algorithm with 5000 bootstrap replicates in order to stabilize individual class error. Redundant (i.e. multicollinear) predictor variables were removed in an early stage of this study (see Falkowski et al., 2009). Finally, and in order to verify that the results from our study were not conditioned by the variable selection method used, we compared the models identified by varSelRF with those from another RF-based algorithm, recently developed in ecological applications (Murphy et al., in press). We found that the models selected by the varSelRF were consistent with the models identified by the other routine.

We assessed the accuracy of the final classifications (i.e. snag and understory shrub presence/absence) using the confusion matrices and errors generated by RF. From these, we calculated the overall accuracy, user and producer accuracies, commission and omission errors, and the kappa statistic (Congalton \& Green, 1999). Although widely used, some studies have criticized the used of the kappa statistic for assessing binary classifications, due to its sensitivity to prevalecence (i.e., the proportions of presences in the data) (see Alluoche et al., 2006 for a review). In order to verify the suitability of the kappa statistic, we compared it to the true skill statistic (TSS; Alluoche et al., 2006), which is a novel variation of kappa that corrects for potential biases introduced by prevalecence. We found insignificant differences between the kappa and TSS values (i.e. maximum difference of 0.03), therefore supporting the use of the kappa statistic in this study.

\subsection{Habitat suitability mapping}

The first step for mapping wildlife habitat suitability involved the aggregation of the LiDAR-derived layers of vegetation structure (i.e. the habitat variables) to 1-ha pixel, because the hectare is the spatial

Table 5

Minority/majority ratios for the different presence/absence classifications.

\begin{tabular}{llll}
\hline & Entire area $(n=83)$ & YMS\&UR $(n=40)$ & MMS\&OMS $(n=26)$ \\
\hline Snags $\geq 15 \mathrm{~cm}$ & $0.98(41 \mathrm{~A} / 42 \mathrm{P})$ & $0.91(19 \mathrm{~A} / 21 \mathrm{P})$ & $0.24(5 \mathrm{~A} / 21 \mathrm{P})$ \\
Snags $\geq 25 \mathrm{~cm}$ & $0.66(33 \mathrm{P} / 50 \mathrm{~A})$ & $0.74(17 \mathrm{P} / 23 \mathrm{~A})$ & $0.63(10 \mathrm{~A} / 16 \mathrm{P})$ \\
Snags $\geq 30 \mathrm{~cm}$ & $0.50(26 \mathrm{P} / 57 \mathrm{~A})$ & $0.48(13 \mathrm{P} / 27 \mathrm{~A})$ & $1.00(13 \mathrm{P} / 13 \mathrm{~A})$ \\
Understory shrubs & $0.73(35 \mathrm{~A} / 48 \mathrm{P})$ & & \\
\hline
\end{tabular}

The number of samples per class (P denotes presence and A denotes absence) used to derive the ratios is shown between parentheses. unit of application of the HSIs used in this study (see Kroll \& Haufle, 2006; Roloff, 2001; Schroeder, 1982; Souza, 1982, 1987). The presence/absence maps of understory shrub and snag distributions were developed at a spatial resolution of $20 \mathrm{~m}$, similar to the field plots. We aggregated these maps to the 1-ha pixel by multiplying the proportion of (20 m-pixel) shrub (or snag) presences found within the 1-ha pixel, by the median plot shrub cover (or snag density) derived from the field data (see Fig. 2). This approach allowed us not only to aggregate the data to the proper spatial scale for HSI mapping (i.e. 1-ha grain size), but also to transform the data from a presence/ absence binary format to a continuous approximation of shrub cover and snag density at the landscape scale. This aggregation approach, however, imposed a maximum threshold of shrub cover and snag density per ha that we could distinguish. In this sense, if all the $20 \mathrm{~m}$ plots located within a 1-ha pixel were predicted as shrub presences, then the percentage of shrub cover for that hectare would be $53 \%$ (= $(25 / 25) * 52.9$; where $25 / 25$ is the proportion of 20 m-pixels with presences and 52.9 is the median plot shrub cover). As a result, we were able to distinguish continuous shrub cover categories below that threshold (53\%) but not above that. Similarly, we were able to distinguish continues snag densities below 50 snags per ha (for classes $\geq 15 \mathrm{~cm}$ and $\geq 25 \mathrm{~cm}$ diameter), and below 25 snags per ha (for the class $\geq 30 \mathrm{~cm}$ diameter), but not above. This issue, however, did not affect the HSI modeling. This is because the habitat suitability values above those shrub and snag densities were constant, making the distinction of more classes unnecessary.

We also aggregated to 1 ha grain size the LiDAR-derived canopy density metric and the map of basal area by Hudak et al. (2008a). In addition, we generated two auxiliary habitat layers reflecting information about the mean diameter of the overstory trees, a variable included in the cover and reproduction components of the HSI for the hairy woodpecker. In this HSI model, the mean diameter (DBH) of the overstory trees was used as a surrogate of forest succession (see Souza, 1987). We made use of the map of forest succession by Falkowski et al. (2009), and recoded the different classes into different habitat suitability values based on 1 ) the mean overstory DBH values observed in the different classes in the field plots, and 2) the relationships between mean DBH and habitat suitability established by Souza (1987). This new auxiliary layer reflects the species' higher preference for mature forests than younger forests.

Once all the habitat geospatial variables were at 1-ha pixel resolution, we applied the HSI formulae for the different avian species. Specifically, the HSI map for the Dusky flycatcher was constructed from the tree canopy cover and understory shrub cover layers; the HSI

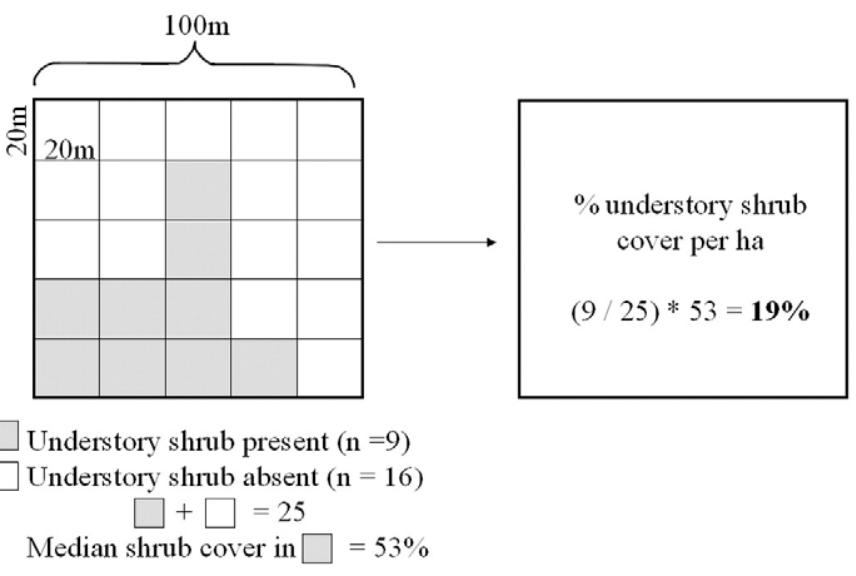

Fig. 2. Aggregation approach for converting the $20 \mathrm{~m}$-pixel LiDAR-based products of understory shrubs presence/absence into continuous, $100 \mathrm{~m}$-pixel (i.e. 1 ha) values. Snags were treated similarly. 
map for the Hairy woodpecker was constructed from the layer of DBH, tree canopy cover and snags $\geq 25 \mathrm{~cm}$ diameter; the HSI map for the Lewis's woodpecker was constructed from the layers of understory shrub cover, snags $\geq 30 \mathrm{~cm}$ diameter, and tree canopy cover; and the HSI map for the Downy woodpecker was constructed with the layers of basal area and snags $\geq 15 \mathrm{~cm}$ diameter (see Table 1 ). The original HSI for the Dusky flycatcher included an additional variable, which is the cover of understory vegetation with height less than $1 \mathrm{~m}$ (Roloff, 2001). This variable, however, receives only half of the weight of the other two variables included in the HSI (see Roloff, 2001), and therefore was not considered in this study. Finally, each final map of habitat suitability included a measure of overall accuracy based on the accuracy of the individual layers used to build the models, as an estimate of error propagation.

\section{Results}

\subsection{Understory shrub distribution mapping}

The understory shrub presence/absence prediction yielded overall and individual class accuracies of $83 \%$. The model included three predictor variables (i.e. LiDAR metrics), including two from canopy (STRATUM0 and STRATUM2) and one from topography (SCOSA) (Table 6). The metric STRATUM0 is the proportion of ground returns (i.e., height $=0 \mathrm{~m}$ ); the metric STRATUM2 is the proportion of vegetation returns between 1 and $2.5 \mathrm{~m}$ in height, and the metric SCOSA (Stage, 1976) describes the percent slope times the cosine of aspect transformation.

\subsection{Snag distribution mapping}

The accuracy of the snag classifications without segmenting the data yielded acceptable overall accuracies, ranging between $72 \%$ and $80 \%$ (Table 7). However, the present category had low accuracies, especially for the snag classes $\geq 25 \mathrm{~cm}$ and $\geq 30 \mathrm{~cm}$. The kappa for classifications without segmentation ranged between 0.43 and 0.59 . The inclusion of a segmentation approach resulted in a net increase in the quality of the classifications. It increased the overall accuracy (ranging now between $86 \%$ and $88 \%$ ), the kappa values (now $\geq 0.7$ ), and the accuracy of both the presence and absence classes. At the same time, it decreased the commission and omission errors (see Table 7). In the classifications without segmentation the accuracy of the individual classes ranged between $58 \%$ and $89 \%$, with most below $80 \%$. After the segmentation, the accuracy of the individual classes ranged between $73 \%$ and $95 \%$, with most above $80 \%$. The number of predictor variables included in the models ranged between 2 and 6 , and included typically a combination of canopy height and topographic metrics. The most common variable was the Median Absolute Deviation of Height (HMAD). Among the topographic variables, landform (i.e. BOLSTAD metrics) and distance to streams (i.e. FLDIST metric) appeared several times.

\subsection{Distribution maps of understory shrubs and snags}

The 20 m-pixel presence/absence maps revealed that less than half of Moscow Mountain has shrubs present in the understory. For the snags, the extent of the different diameter classes decreased rapidly with increasing snag diameters, from $45 \%$ of the study area for the snags $\geq 15 \mathrm{~cm}$ to $30 \%$ for the snags $\geq 30 \mathrm{~cm}$ (Fig. 3 ). At the hectare scale, the map of understory shrub density revealed that less than $10 \%$ of the total area had more than $50 \%$ of understory shrub cover per ha. Areas with shrub cover between $25 \%$ and $50 \%$ per ha represented about $40 \%$ of the study area, and the remaining $50 \%$ of Moscow Mountain was dominated by very low or no shrub cover. The density of snags per hectare rapidly decreased with increasing snag diameters (Fig. 3).

\subsection{Habitat suitability modeling}

The spatial representation of the HSI models revealed the presence of different patterns of habitat suitability and habitat availability for the four different avian species (Fig. 4). For the Lewis's woodpecker, a species that uses snags and understory shrubs, approximately half of Moscow Mountain was unsuitable $(\mathrm{HSI}=0.0)$. Approximately $15 \%$ of the area could be deemed "suitable" (considered as areas with $\mathrm{HSI} \geq 0.6$ [Prosser \& Brooks, 1998]) and there were no optimum habitats (i.e. HSI =1.0). For the dusky flycatcher, a species associated with understory shrubs, the amount of suitable habitat was also low, with no optimum areas. For the hairy woodpecker and the downy woodpecker, two relatively common species, few areas were determined to be unsuitable (i.e. HSI $=0.0$ ), and about one third of Moscow Mountain habitat was suitable $(\mathrm{HSI} \geq 6)$. However, the suitable habitat for these species occurred in different portions of Moscow Mountain, reflecting the different habitat requirements (see Table 1). Some areas, although small, were classified as optimum habitats for these two avian species.

The final accuracy of the HSI maps (after adding the errors of the input layers) ranged between $79 \%$ and $91 \%$. Specifically, the HSI map accuracy was $79 \%$ for the hairy woodpecker, $90 \%$ for the Lewis's woodpecker, $92 \%$ for the dusky flycatcher, and $92 \%$ for the downy woodpecker.

\section{Discussion and conclusions}

The lack of spatial data about snags and understory shrub distribution is a recognized limitation for managing wildlife habitat in forests (Russell et al., 2007; Venier \& Pearce, 2007). We found that LiDAR data provided valuable information for mapping the distribution of snags, understory shrubs, and wildlife habitat suitability in a mixedconifer forest, representing an important step in the characterization of forest structure and wildlife habitat with remote sensing.

Metrics of canopy height and topography derived from LiDAR allowed us to map the distribution of understory shrubs with an

Table 6

Accuracy statistics for the model of understory shrub presence/absence.

\begin{tabular}{|c|c|c|c|c|c|c|c|c|}
\hline \multicolumn{9}{|c|}{ Understory shrub } \\
\hline & & \multicolumn{2}{|c|}{ Actual data } & \multirow[b]{2}{*}{ Sum } & \multirow[b]{2}{*}{ Producer's accuracy (\%) } & \multirow[b]{2}{*}{ User's accuracy (\%) } & \multirow[b]{2}{*}{ Omission error } & \multirow[b]{2}{*}{ Commission error } \\
\hline & Class & Present & Absent & & & & & \\
\hline \multirow[t]{3}{*}{ Predicted data } & Present & 40 & 6 & 46 & 83 & 87 & 0.17 & 0.13 \\
\hline & Absent & 8 & 29 & 37 & 83 & 78 & 0.17 & 0.22 \\
\hline & Sum & 48 & 35 & 83 & & & & \\
\hline
\end{tabular}

Overall accuracy $=83 \%$; kappa $=0.66$; TSS $=0.66$.

Predictor variables: STRATUM0, SCOSA, STRATUM2. 
Table 7

Accuracy statistics for the different models of the presence/absence of snags, including with and without segmentation.

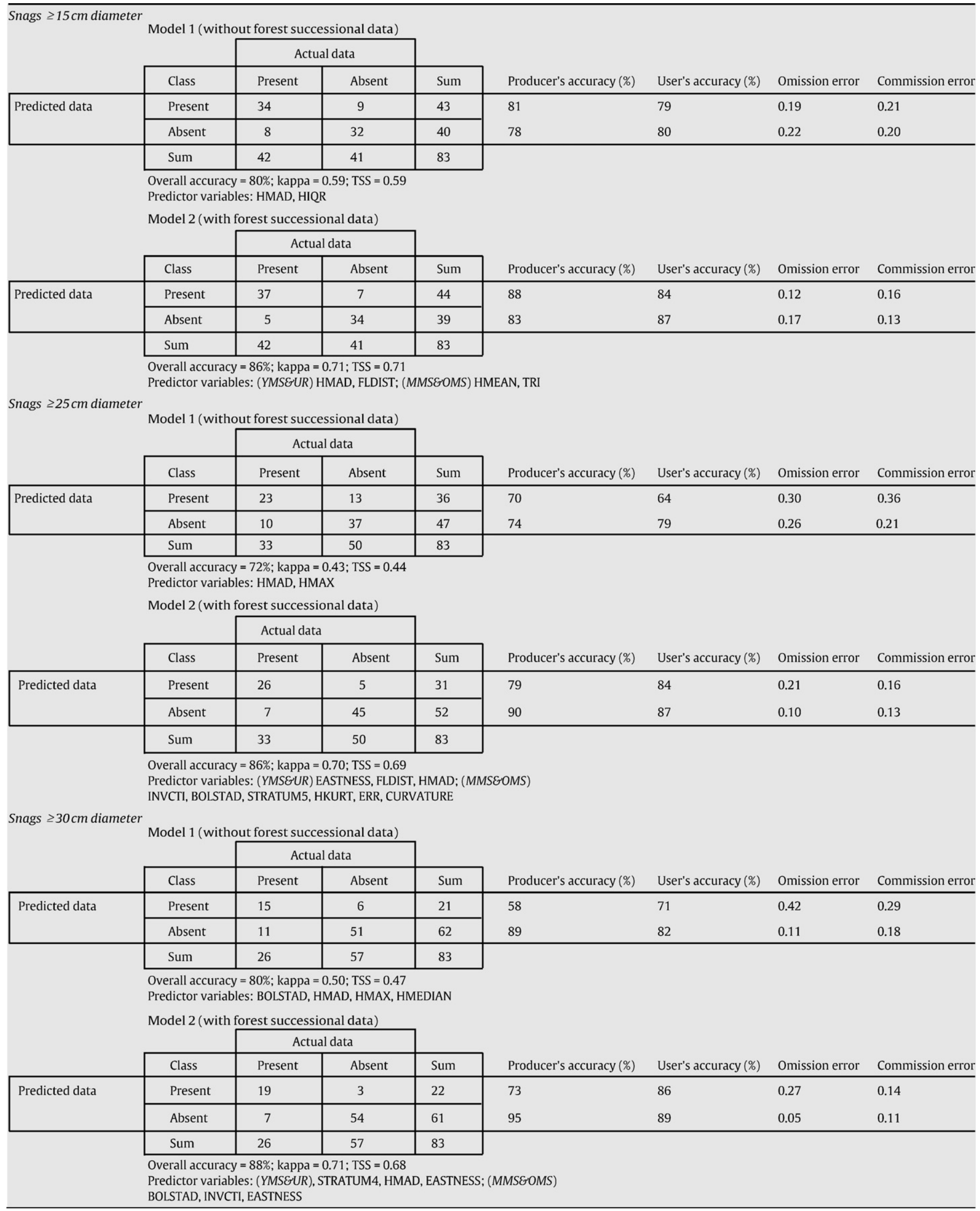




\section{SNAG DISTRIBUTION MAPS}

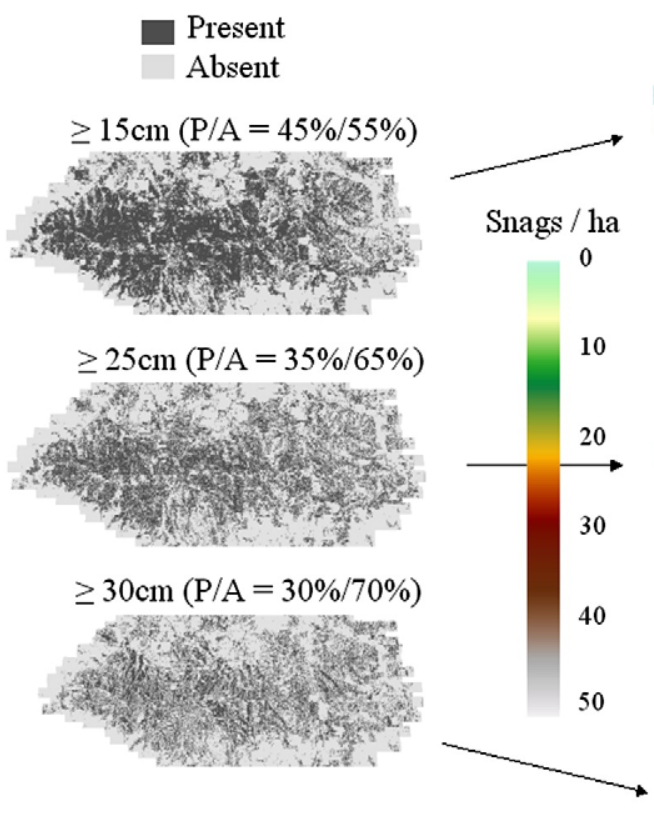

\section{UNDERSTORY SHRUBS DISTRIBUTION MAPS}

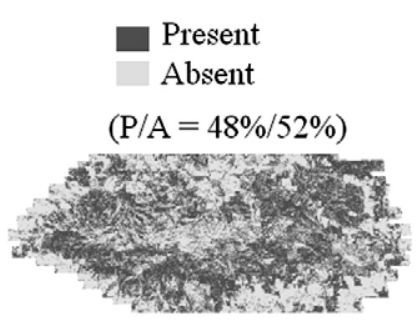

Understory

shrub cover / ha

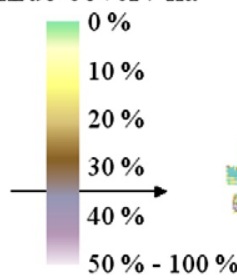

$\geq 15 \mathrm{~cm}$
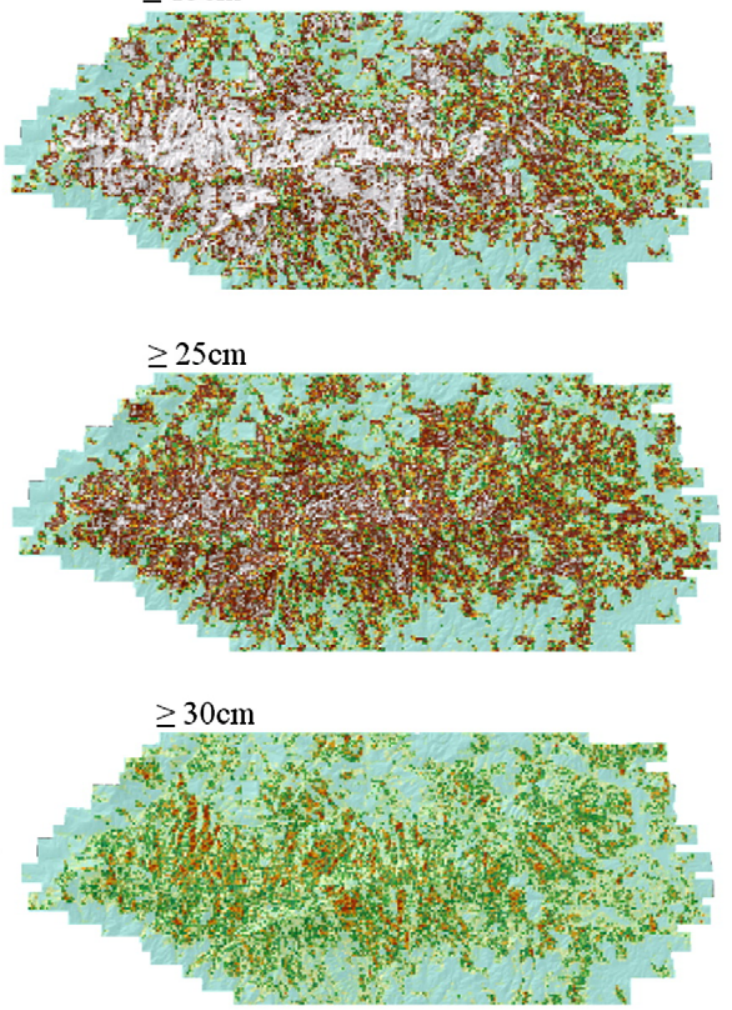

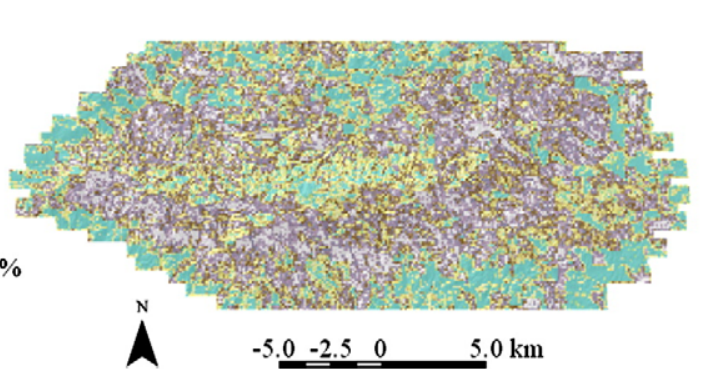

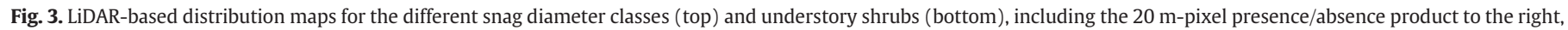
and the 1-ha density map to the left. The presence/absence maps include, between parentheses, the proportional cover of the two classes (i.e. present vs. absent).

overall and individual class accuracy of more than $80 \%$. Only three metrics were needed, including two from canopy (STRATUM0 and STRATUM2), and one from topography (SCOSA). STRATUM0 (the percentage of ground returns) is inversely proportional to canopy density (percentage of non-ground returns $\geq 1 \mathrm{~m}$ in height; $r^{2}=0.73$ ). Previous research indicated that forests with open canopies tend to support more shrubs than those with closed canopies (Bartemucci et al., 2006; Kilina et al., 1996). Analysis of conditional density function plots (CDF) for the shrub field data vs. the percent of ground returns from LiDAR revealed that the previous finding (i.e. more shrubs under open canopies) is true for both young and mature forests (Fig. 5 top). In young and mature forest plots, which reported less than $40 \%$ ground returns, the presence of shrubs (as measured by the proportion of shrub presences) decreased with decreasing amounts of ground LiDAR returns. In other words, forest tree canopies that intercepted fewer LiDAR pulses tended to have more shrubs than those that intercepted more pulses, a result agreeing with the ecological findings of Kilina et al. (1996) and Bartemucci et al. (2006). Information about the percentage of ground returns might also capture variations in shrub cover due to management practices, which is another factor influencing the distribution of shrubs in forested landscapes (Kerns \& Ohmann, 2004). In plots with high values of ground returns ( $\geq 40 \%)$, and consequently with very low or absent tree canopy cover, shrubs were primarily absent, contrary to the general expectation (see Fig. 5 top). This region of the CDF plot includes, among others, the 9 open area plots, of which 8 have no shrubs, and most of the stand initiation plots, half of which have no shrubs either. Management practices typically prevent the development of shrubs in areas with trees recently planted or to maintain the open areas in grasslands. Kerns and Ohmann (2004) found similar responses in the coastal forests of Oregon, with open forests supporting lower than expected shrub cover, due to forest management.

Topography is another variable known to influence the presence of shrubs in temperate forests (Gracia et al., 2007). The variable SCOSA reflects topographic positions based on slope and aspect simultaneously. The CDF plot revealed that northern aspects and steeper slopes (i.e. high SCOSA values) supported fewer shrubs than southern aspects and gentler slopes (lower SCOSA values) (Fig. 5 center). In the region of our study, northern aspects are colder and steep slopes are drier, thus less suitable for the development of broad-leaf understory shrubs.

Finally, the variable STRATUM2 corresponds to the percent of vegetation returns between $1 \mathrm{~m}$ and $2.5 \mathrm{~m}$ height, a range where interaction of the laser pulses with the shrub layer can be expected. 

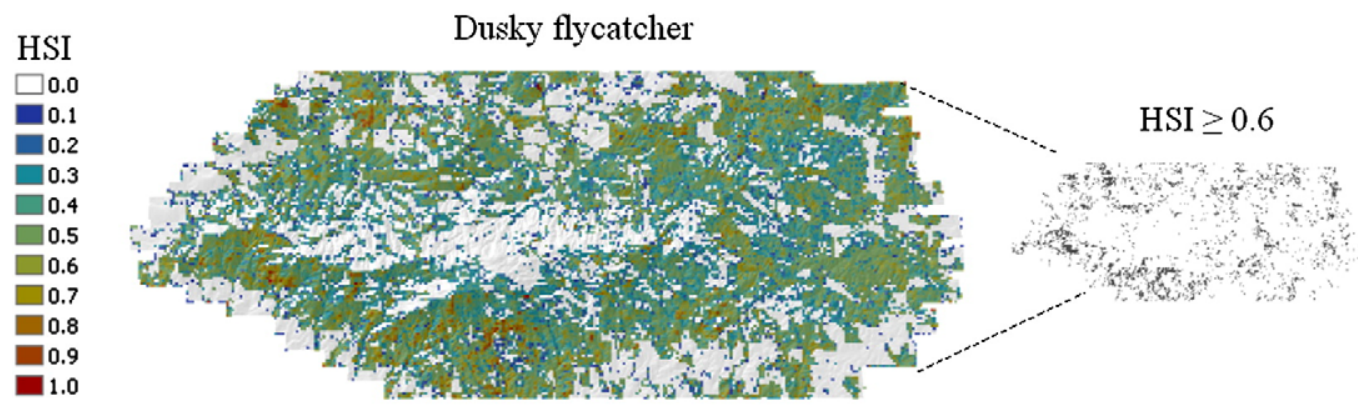

HSI
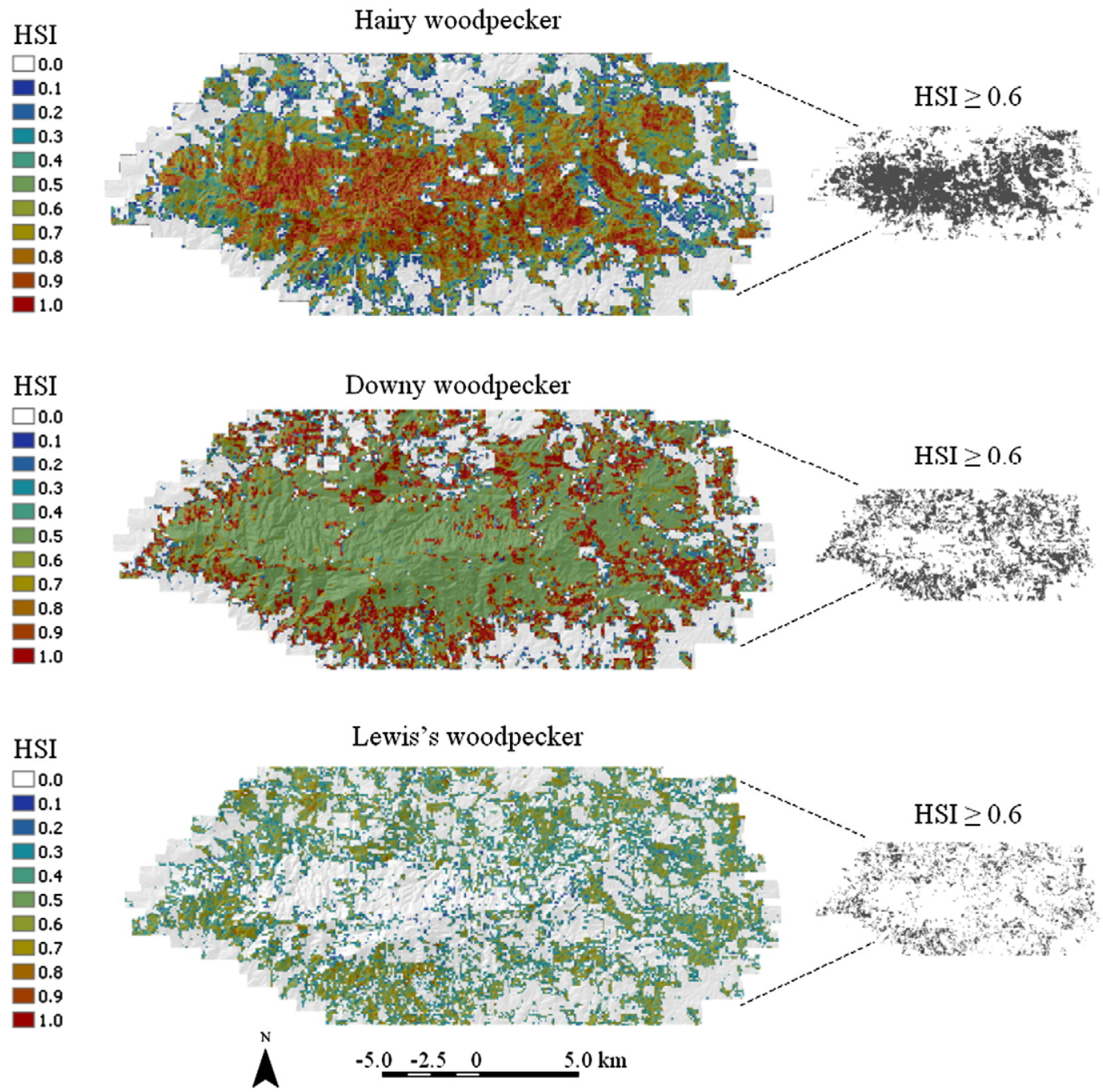

Fig. 4. Habitat suitability maps for the different avian species. The maps on the right are simplified, aggregated and recoded versions depicting areas with habitat suitability index (HSI) $\geq 0.6$ (i.e. suitable habitats).

According to the field data, the shrub cover was typically less than $2 \mathrm{~m}$ in height. The CDF revealed that most of the field plots (72 of 83) in the study area have less than $20 \%$ of the vegetation returns in the STRATUM2 layer, and within these plots, those with more returns in the STRATUM2 layer tend to have more shrubs (as measured by the proportion of shrub presences) (Fig. 5 bottom). This supports the idea that shrubs are contributing to many of the returns found in this layer. However, there were cases with no true shrubs in the understory but still a high proportion of returns within the STRATUM2 layer, indicating the presence of other components in the understory (e.g. saplings and lower branches of small trees). In the CDF plot, for example, the peak in the absences observed in STRATUM2 values of around 30\% was caused by plots of stand initiation and understory reinitiation, which have low tree cover with high understory cover composed only by conifers.

One of the major challenges for characterizing understory vegetation with LiDAR data is that increased forest cover reduces the chances of detecting understory returns (Goodwin, 2006; Goodwin et al., 2007), which complicates applications in areas containing dense canopies. In addition, not all understory "shrubby" vegetation is equally relevant for wildlife species, particularly in Pacific Northwest coniferous forests (Hagar, 2007). The use of LiDAR data allowed us to map the distribution of understory shrub species by quantifying not only vegetation returns from the lower strata of the canopy forest (i.e. 

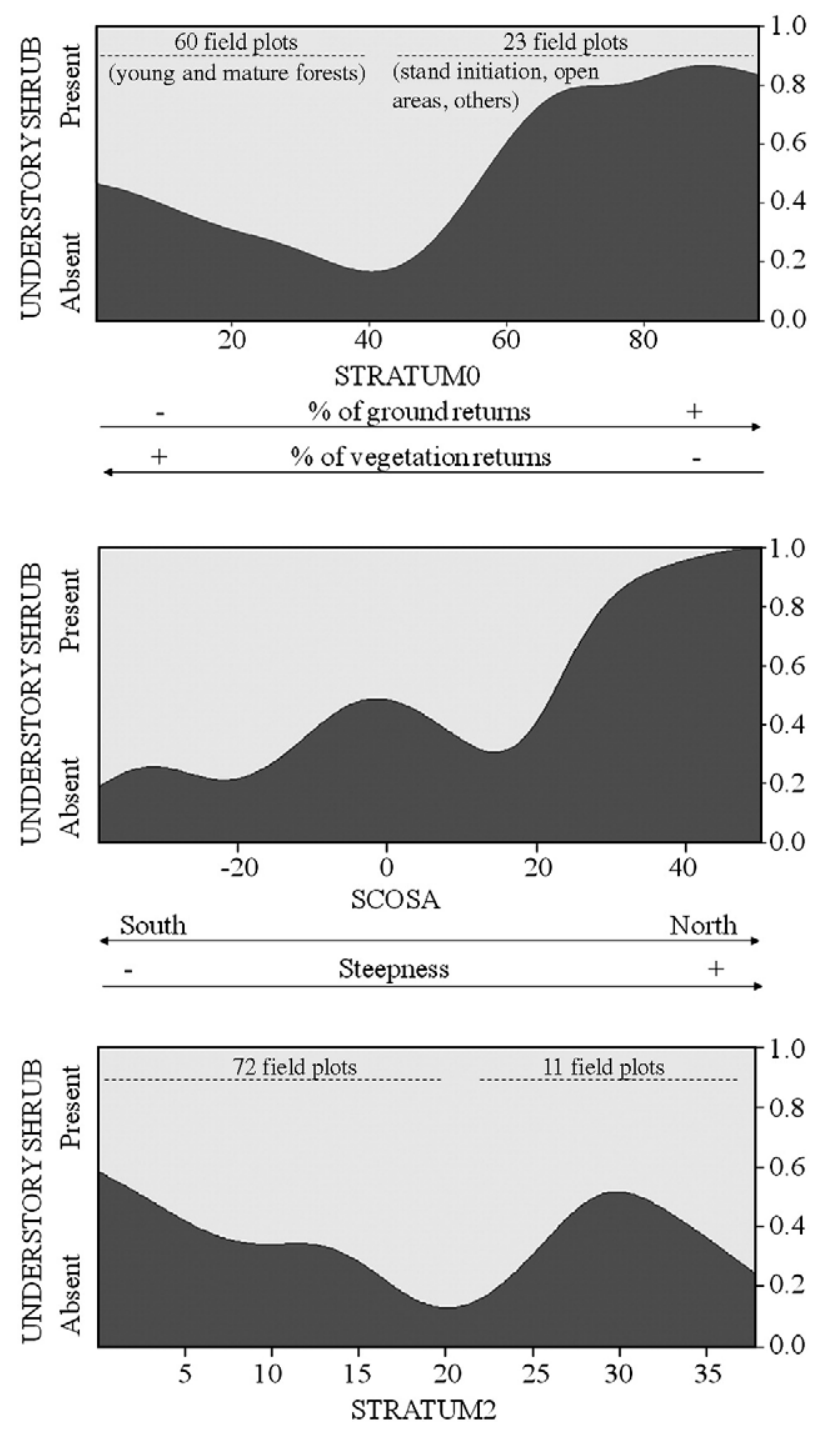

Fig. 5. Conditional density plots for the understory shrub distribution vs. the 3 (LiDARderived) predictor variables included in the final model.

where understory shrubs occur), but also ecological variables (e.g. tree canopy cover and topography) that are known to influence the distribution and abundance of understory vegetation in closed and open forests. We found that the errors in our understory shrub map were distributed in similar proportions under open and closed canopies (as reflected by the canopy density metric, using a threshold of $50 \%$ to separate low vs. high), suggesting that the model was useful under both open and dense tree canopies.

The results of this study indicated that the Median Absolute Deviation of Height LiDAR returns (HMAD) is an important variable for predicting the distribution of different diameter classes of snags, as it was the most common variable selected in the models. Bater et al. (2007) found that a similar LiDAR-derived measure of canopy variation, the log-transformed coefficient of variation of heights, was a significant predictor of the proportion of trees in different stages of decay. Clark et al. (2004) and Bater et al. (2007) suggested that canopies became more structurally complex (or variable) partly because of the presence of snags. Our CDF plot revealed that the presence of snags increased with increasing canopy complexity as reflected by HMAD (Fig. 6). The findings of this study reinforce the notion that LiDAR-derived measures of variation in canopy height are valuable for characterizing the distribution of snags and trees in different stages of decay, whether in terms of overall abundance
(Bater et al., 2007), or in terms of abundance of different diameter classes (this study). Pesonen et al. (2008) found that the logtransformed coefficient of variation of heights from LiDAR was also a significant predictor of downed woody debris. In addition, while the study of Bater et al. (2007) was conducted in a flat area, our study was conducted in complex topography. Topography is a common factor influencing the abundance of snags and dead woody material in mountainous areas (Flanagan et al., 2002; Kennedy et al., 2008), and it appeared to be important in our study area as most of the models included LiDAR-derived topographic variables. For example, we observed a higher proportion of samples with snags in areas with more exposed, convex terrain (positive BOLSTAD values) than under more protected, concave terrain (negative BOLSTAD values) (data not shown). Similar to the shrubs, the use of LiDAR metrics allowed us to quantify structural variables that are known to indirectly indicate the presence of snags, as well as environmental variables that are known to influence their presence and distribution in forests. Finally, we found that the incorporation of information about forest succession (derived also from LiDAR; Falkowski et al., 2009) improved the accuracy of the predictive distribution for the different snag diameter classes. The age of the stand can be a natural indicator of the potential diameter of the snags found in the forests (typically, the older the forests, the larger the snags). We found that the segmentation based on succession produced areas with different HMAD values (e.g. HMAD for MMS $=9.2 \pm 3.5$; HMAD for YMS\&UR $=3.3 \pm 3.4$ ), effectively reducing variation in relevant data, for a better classification. The accuracy of the different snag diameter classes was slightly higher in the MMS\&OMS successional area (88\%) than in the YMS\&UR area (77\% to $82 \%)$.

In summary, for snags and understory shrub mapping, the value of LiDAR data resided in the ability to quantify 1 ) structural metrics that are known to directly or indirectly indicate the presence of understory shrubs and snags, such as the percent of vegetation returns in the lower strata of the canopy (for the shrubs) and the vertical heterogeneity of the forest canopy (for the snags), and 2) ecological variables that are known to influence the distribution and abundance of understory vegetation and snags in temperate mountainous forests (e.g. canopy cover, topography, forest succession).

The RF algorithm (Breiman, 2001) played an important role in these findings, as it allowed us to identify those relevant predictor variables for understory shrub and snags mapping, and integrate them in a predictive mapping approach. Similar to Cutler et al. (2007) and Falkowski et al. (2009), we found that the variables identified by RF agreed with the expectations based on the literature, making good intuitive sense in how the variables relate to the ecological processes governing snag and understory shrub distribution, and highlighting the value of the RF algorithm for ecological modeling using remote sensing data.

For wildlife habitat suitability assessment, the value of LiDAR data resided in its ability to derive a variety of habitat variables related to forest 3-D structure, which are known to be important for wildlife

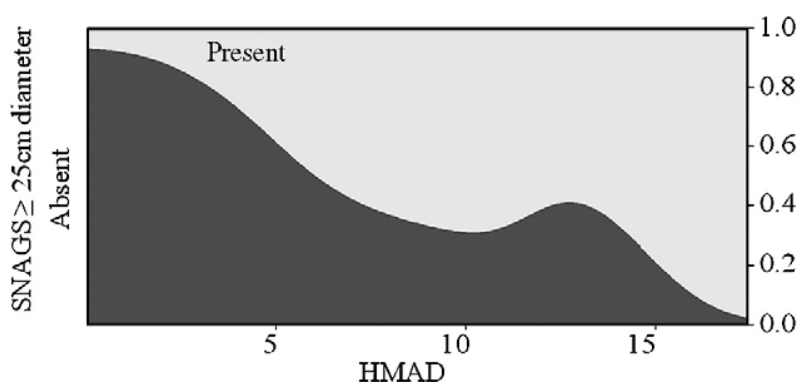

Fig. 6. Conditional density plots for the snag distribution vs. the (LiDAR-derived) Median Absolute Deviation of Heights (HMAD). The figure shows the example for the snag diameter class $\geq 25 \mathrm{~cm}$, but a similar trend was observed for the other snag classes. 
species, but have been difficult or impossible to derive from other remote sensing technologies (see Vierling et al., 2008). In this sense, we were able to map habitat suitability for avian species that depend on a broad variety of forest structural conditions (including those related to understory vegetation, snag size and density, tree canopy cover, basal area, etc.). These findings are important for advancing the management of biodiversity and wildlife habitat in forests (Russell et al., 2007; Venier \& Pearce, 2007), biodiversity applications of remote sensing (Turner et al., 2003), and species distribution modeling (Guisan \& Zimmerman, 2000). For instance, the lack of maps of understory shrub and snag distribution has been identified as a major limitation for managing wildlife habitat in forests (Russell et al., 2007; Venier \& Pearce, 2007). In our case, we mapped understory shrubs from an initial presence/absence approach. While the availability of a simple presence/absence layer can make a difference in assessing wildlife habitat suitability (see for example the Giant Panda's case in Linderman et al., 2005), further efforts should evaluate the capabilities of LiDAR data to derive continuous estimates of understory shrub cover at the plot level and below any type of overstory condition. Goodwin (2006) and Goodwin et al. (2007) suggested that increasing the plot size might serve to detect more returns from the understory. In a recent study, Korpela (2008) found that calibrated LiDAR intenity data is sensitive to understory, ground-surface composition. Because true shrubs and saplings found in the understory of Inland Northwest forests are compositionally and functionally different (i.e. nonconiferous vs. coniferous), there is potential in the use of calibrated intensity data for understory characterization (but see Su \& Bork, 2007). Because the intensity data were not calibrated, we chose not to include intensity information in our study.

In terms of snags, it is important to expand the LiDAR-based mapping approach to other diameter classes. We focused on common snags used by some species of woodpecker, but larger snag classes (e.g. $\geq 50 \mathrm{~cm}$ DBH) are also of critical interest for wildlife and biodiversity assessment (Davis, 1983). However, especially in highly managed/harvested forests, these snag classes can be rare (see Fig. 1), and thus, working with them may require other sampling approaches (see for example Bate et al., 2002) and/or dealing with heavily imbalanced data that can present challenges for classification (Chen et al., 2004). The use of high-spatial resolution, color infrared aerial photos has proved useful for mapping the distribution of large snags in a forest by photo interpretation (Bütler \& Schlaepfer, 2004). The integration of high-density LiDAR data and high-spatial and spectral resolution imagery might facilitate the mapping of more snag classes, as well as the identification of patches dominated by dead trees (see Swatantran et al., 2008).

LiDAR data have proved useful for assessing wildlife habitat in forests (see review by Vierling et al., 2008), including in our study. However, these efforts encompass a small total number of species and have been conducted at a relatively small spatial scale. A similar spatial situation can be found in the analyses of biodiversity/species richness with LiDAR (see Goetz et al., 2007 and Clawges et al., 2008). As a result, expanding the applications to other areas and to other organisms with different habitat requirements is highly desired. In addition, it is also important to evaluate which type of LiDAR information (i.e., rough data, metrics and/or variables) are needed to support wildlife habitat suitability and biodiversity assessments. For instance, Bater (2008) evaluated which of the known indicators of forest biodiversity in Canada can be derived from LiDAR, and Martinuzzi et al. (2009) did the same for habitat variables that are needed for refining predictions of species distribution by the US Gap Analysis Program. Expanding the applications of LiDAR remote sensing for wildlife habitat and biodiversity assessments should be feasible considering the increasing availability of LiDAR data. Furthermore, these efforts are particularly relevant for evaluating the potential of future large-scale LiDAR acquisitions, such as those related to the US National LiDAR Initiative (Stoker et al., 2008) or the
NASA's planned DESDynI (Deformation, Ecosystem Structure and Dynamics of Ice) mission (http://desdyni.jpl.nasa.gov/).

\section{Acknowledgements}

This work was made possible through funding by the USGS Gap Analysis Program and the USDA Forest Service International Institute of Tropical Forestry (IITF). The LiDAR acquisition, processing, and analysis were supported by the Agenda 2020 program, a research partnership between the USFS Rocky Mountain Research Station, Bennett Lumber Products, Inc., and Potlatch Forest Holdings, Inc., and the University of Idaho. We thank G. Roloff for facilitating the HSI model for the dusky flycatcher, R. Nelson for commenting on an earlier version of this manuscript, N. Crookston and R. Díaz-Uriarte for fruitful discussions about Random Forest and varSelRF, and three anonymous reviewers. Work at IITF is done in collaboration with the University of Puerto Rico.

\section{References}

Alluoche, O., Tsoar, A., \& Kadmon, R. (2006). Assessing the accuracy of species distribution models: Prevalence, kappa and the true skill statistic (TSS). Journal of Applied Ecology, 43, 1223-1232.

Bartemucci, P., Messier, C., \& Canham, C. D. (2006). Overstory influences on light attenuation patterns and understory plant community diversity and composition in southern boreal forests of Quebec. Canadian Journal of Forest Research, 36, 2065-2079.

Bate, L. S., Garton, E. O., \& Wisdom, M. J. (2002). Sampling methods for snags and large trees important for wildlife. USDA Forest Service General Technical Report PSW-GTR181.

Bater, C. W. (2008). Assessing indicators of forest sustainability using LiDAR remote sensing (Thesis). University of British Columbia, Vancouver, Canada (97 pp.).

Bater, C. W., Coops, N. C., Gergel, S. E., \& Goodwin, N. R. (2007). Towards the estimation of tree structural class in northwest coastal forest using LiDAR remote sensing. Proceedings of the ISPR Workshop “Laser Scanning 2007 and SilviLaser 2007", Espoo, September 12-14, 2007, Finland, Vol. XXXVI. (pp. 38-43) ISSN:1682-1777, P3/W52.

Breiman, L. (2001). Random Forests. Machine Learning, 45, 5-32.

Brokaw, N. V., \& Lent, R. A. (1999). Vertical structure. In M. Hunter (Ed.), Maintaining biodiversity in forest ecosystems (pp. 373-399). Cambridge: Cambridge University Press.

Broughton, R. K., Hinsley, S. A., Bellampy, P. E., Hill, R., \& Rothery, P. (2006). Marsh Tit Poecile palustris territories in a British broad-leaved wood. Ibis, 148, 744-752.

Bütler, R., \& Schlaepfer, R. (2004). Spruce snag quantification by coupling colour infrared aerial photos and a GIS. Forest Ecology and Management, 195, 325-339.

Chen, C., Liaw, A., \& Breiman, L. (2004). Using random forest to learn imbalanced dataTechnical report, Vol. 666. Statistics Department, University of California at Berkeley.

Clark, D. B., Castro, C. S., Alvarado, L. D. A., \& Read, J. M. (2004). Quantifying mortality of tropical rain forest trees using high-spatial-resolution satellite data. Ecology Letters, 7, 52-59.

Clawges, R., Vierling, L. A., Calhoon, M., \& Toomey, M. P. (2007). Use of a ground-based scanning lidar for estimation of biophysical properties of western larch (Larix occidentalis). International Journal of Remote Sensing, 28, 4331-4344.

Clawges, R., Vierling, K., Vierling, L., \& Rowell, E. (2008). The use of airborne lidar to assess avian species diversity, density, and occurrence in a pine/aspen forest. Remote Sensing of Environment, 112, 2064-2073.

Cline, S. P., Berg, A. B., \& Wight, H. M. (1980). Snag characteristics and dynamics in Douglas-fir forests, western Oregon. Journal of Wildlife Management, 44, 773-786.

Congalton, R., \& Green, K. (1999). Assessing the accuracy of remotely sensed data: Principles and practices. Boca Raton, FL: CRC/Lewis Press. 137 pp.

Cooper, S. V., Neiman, K. E., \& Roberts, D. W. (1991). Forest habitat types of Northern Idaho: A second approximation. USDA Forest Service IRS, GTR-INT-236. $143 \mathrm{pp}$

Crookston, N. L., \& Finley, A. O. (2008). yalmpute: An R package for KNN imputation. Journal of Statistical Software, 23(10) $16 \mathrm{pp}$.

Cutler, R. D., Edwards, T. C., Jr., Beard, K. H., Cutler, A., Hess, K. T., Gibson, J., et al. (2007). Random Forests for classification in ecology. Ecology, 88, 2783-2792.

Davis, J. W. (1983). Snags are for wildlife. In J. W. Davis, G. A. Goodwin, \& R. A. Ockenfels (Eds.), Proceedings of the Symposium on Snag Habitat Management. USDA Forest Service General Technical Report RM-99. (pp. 4-9) : Flagstaff, AZ.

Díaz-Uriarte (2008). The varSelRF package. 23 pp. Available at: http://cran.r-project. org/web/packages/varSelRF/varSelRF.pdf

Díaz-Uriarte, R., \& Alvarez, S. (2006). Gene selection and classification of microarray data using random forest. BMC Bioinformatics, 7, 3.

Drake, J., Dubayah, R. O., Clark, D. A., Knox, R. G., Blair, B., Hofton, M., et al. (2002). Estimation of forest structural characteristics using large-footprint lidar. Remote Sensing of Environment, 79, 305-319.

Edenius, L., \& Mikusiński, G. (2006). Utility of habitat suitability models as biodiversity assessment tools in forest management. Scandinavian Journal of Forest Research, 21, $62-72$. 
Evans, J. S., \& Hudak, A. T. (2007). A multiscale curvature algorithm for classifying discrete return LiDAR in forested environments. IEE Transactions on Geoscience and Remote Sensing, 45, 1029-1038.

Falkowski, M. J., Evans, J. S., Martinuzzi, S., Gessler, P. E., \& Hudak, A. T. (2009). Characterizing forest succession with Lidar data: An evaluation for the inland Northwest USA. Remote Sensing of Environment, 113, 946-956.

Falkowski, M. J., Gessler, P. E., Morgan, P., Hudak, A. T., \& Smith, A. M. S. (2005) Evaluating ASTER satellite imagery and gradient modeling for mapping and characterizing wildland fire fuels. Forest Ecology and Management, 217, 129-146.

Flanagan, P. T., Morgan, P., \& Everett, R. L. (2002). Snag recruitment in subalpine forest of the North Cascades, Washington State. USDA Forest Service General Technical Report PSW-DTR-181.

Frescino, T. S., Edwards, T. C., \& Moisen, G. G. (2001). Spatially explicit forest structural attributes using generalized additive models. Journal of Vegetation Science, 12, 15-26.

Fu, W. J., Raymond, J. C., \& Wand, S. (2005). Estimating misclassification error with small samples via bootstrap cross-validation. Bioinformatics, 21, 1979-1986.

Ganey, J. L. (1999). Snag density and composition of snag populations in two National Forests in northern Arizona. Forest Ecology and Management, 117, 169-178.

Goetz, S., Steinberg, D., Dubayah, R., \& Blair, B. (2007). Laser remote sensing of canopy habitat heterogeneity as a predictor of bird species richness in an eastern temperate forest, USA. Remote Sensing of Environment, 108, 254-263.

Goodwin, N. R. (2006). Assessing understorey structural characteristics in eucalyptus forests: An investigation of LiDAR techniques (Thesis). University of New South Wales, Sydney NSW Australia (206 pp.).

Goodwin, N. R., Coops, N. C., Bater, C., \& Gergel, S. E. (2007). Assessment of sub-canopy structure in a complex coniferous forest. Proceedings of the ISPR Workshop "Laser Scanning 2007 and SilviLaser 2007", Espoo, September 12-14, 2007, Finland, Vol. XXXVI. (pp. 169-172) ISSN:1682-1777, P3/W52.

Gracia, M., Montané, F., Piqué, J., \& Retana, J. (2007). Overstory structure and topographic gradients determining diversity and abundance of understory shrub species in temperate forests in central Pyrenees (Spain). Forest Ecology and Management, 242, $391-397$.

Graf, R. F., Mathys, L., \& Bollmann, K. (2009). Habitat assessment for forest dwelling species using LiDAR remote sensing: Capercaillie in the Alps. Forest Ecology and Management, 257, 160-167.

Guisan, A., \& Zimmerman, N. E. (2000). Predictive habitat distribution models in ecology. Ecological Modelling, 135, 147-186.

Hagar, J. C. (2007). Wildlife species associated with non-coniferous vegetation in Pacific Northwest forests: A review. Forest Ecology and Management, 246, 108-122.

Harding, D. J., Lefksy, M. A., Parker, G. G., \& Blair, J. B. (2001). Laser altimeter canopy height profiles: Methods and validations for closed-canopy, broadleaf forests. Remote Sensing of Environment, 76, 283-297.

Hill, R. A., \& Broughton, R. K. (2009). Mapping understorey from leaf-on and leaf-off airborne LiDAR data of deciduous woodland. ISPRS Journal of Photogrammetry and Remote Sensing, 64, 223-233.

Hinsley, S. A., Hill, R. A., Bellampy, P.E., Harrison, N. M., Speakman, J. R., Wilson, A. K., et al. (2008). Effects of structural and functional habitat gaps on breeding woodland birds: Working harder for less. Landscape Ecology, 23, 615-626.

Hinsley, S. A., Hill, R. A., Gaveau, D. L. A., \& Bellampy, P. E. (2002). Quantifying woodland structure and habitat quality for birds using airborne laser scanning. Functional Ecology, 16, 851-857.

Hofton, M. A., Rocchio, L. E., Blair, J. B., \& Dubayah, R. (2002). Validation of vegetation canopy lidar sub-canopy topography measurements for a dense tropical forest. Journal of Geodynamics, 34, 491-502.

Huang, C., Homer, C., \& Yang, L. (2003). Regional forest land cover characterization using Landsat type data. In M. Wulder \& M. Franklin (Eds.), Methods and application for remote sensing of forests: Concepts and case studies (pp. 389-410). Kluwer, Academic Publishers.

Hudak, A. T., Crookston, N. L., Evans, J. S., Falkowski, M. J., Smith, A. M.S., Gessler, P. E., et al. 2006). Regression modeling and mapping of coniferous forest basal area and tree density from discrete-return lidar and multispectral satellite data. Canadian Journal of Remote Sensing, 32, 126-138.

Hudak, A. T., Crookston, N. L., Evans, J. S., Hall, D. E., \& Falkowski, M. J. (2008). Nearest neighbor imputation modeling of species-level, plot-scale structural attributes from LiDAR data. Remote Sensing of Environment, 112, 2232-2245.

Hudak, A. T., Evans, J. S., Crookston, N. L., Falkowski, M. J, Steigers, B., Tylor, R., et al. (2008). Aggregating pixel-level basal area predictions derived from LiDAR data to industrial forest stands in Idaho. In R. N. Havis \& N.L Crookston (Eds.), Third Forest Vegetation Simulator Conference 2007. USDA Forest Service, Rocky Mountain Research Station; Proceedings RMRS-P-54 (pp. 133-146). (refereed).

Hyde, P., Dubayah, R., Peterson, B., Blair, J. B., Hofton, M., Hunsaker, C., et al. (2005) Mapping forest structure for wildlife habitat analysis using waveform lidar: Validation of montane ecosystems. Remote Sensing of Environment, 96, 427-437.

Hyde, P., Dubayah, R., Walker, W., Blair, J. B., Hofton, M., \& Hunsaker, C. (2006). Mapping forest structure for wildlife habitat analysis using multi-sensor (LiDAR, SAR/InSar, $\mathrm{ETM}+$, Quickbird) synergy. Remote Sensing of Environment, 102, 63-73.

Kennedy, R. S. H, Spies, T. A., \& Gregory, M. J. (2008). Relationships of dead wood patterns with biophysical characteristics and ownership according to scale in Coastal Oregon, USA. Landscape Ecology, 23, 55-68.

Kerns, B. K., \& Ohmann, J. L. (2004). Evaluation and prediction of shrub cover in coastal Oregon forests (USA). Ecological Indicators, 4, 83-98.

Kerr, J. T., \& Ostrovsky, M. (2003). From space to species: Ecological applications for remote sensing. Trends in Ecology and Evolution, 18, 299-305.

Kilina, AK, Chen, H. Y. H., Wang, Q., \& Montigny, L. (1996). Forest canopies and their influence of understory vegetation in early seral stands on west Vancouver island. Northwest Science, 70, 193-200.
Korol, J. J., Hemstrom, M. A., Hann, W. J., \& Gravenmier, R. A. (2002). Snags and down wood in the interior Columbia Basin Ecosystem Management Project. USDA Forest Service General Technical Report PSW-GTR-181.

Korpela, I. S. (2008). Mapping of understory lichens with airborne discrete-return LiDAR data. Remote Sensing of Environment, 112, 3891-3897.

Kroll, A. J., \& Haufle, J. B. (2006). Development and evaluation of habitat suitability models at multiple spatial scale: A case study with the dusky flycatcher. Forest Ecology and Management, 229, 161-169.

Lawrence, R. L., Wood, S. D., \& Sheley, R. L. (2006). Mapping invasive plants using hyperspectral imagery and Breiman Cutler classifications (RandomForest). Remote Sensing of Environment, 100, 356-362.

Lefsky, M. A., Cohen, W. B., Harding, D. J., \& Parker, G. G. (2002). Lidar remote sensing for forest ecosystem studies. BioScience, 52, 19-30.

Liaw, A., \& Wiener, M. (2002). Classification and regression by Random-Forest. $R$ News, $2,18-22$.

Linderman, M., Beaer, S., An, L., Tan, Y. C., Ouyang, Z. Y., \& Liu, H. G. (2005). The effects of understory bamboo or broad-scale estimated of giant panda habitat. Biological Conservation, 121, 383-390.

MacArthur, R. H., \& MacArthur, J. W. (1961). On bird species diversity. Ecology, 42, 594-598.

Maltamo, M., Packalén, P., Yu, X., Eerikäinen, K., Hyyppä, J., \& Pitkänen, J. (2005). Identifying and quantifying structural characteristics of heterogeneous boreal forests using laser scanner data. Forest Ecology and Management, 216, 41-50.

Martinuzzi, S., Vierling, L., Gould, W., \& Vierling, K. (2009). Improving the characterization and mapping of wildlife habitats with LiDAR data: Measurement priorities for the Inland Northwest, USA. In J. Maxwell (Ed.), Gap analysis bulletin No. 16. USGS/BRD/Gap Analysis Program, Moscow, ID, USA.

McDermid, G. J., Franklin, S. E., \& LeDrew, E. F. (2005). Remote sensing for large-area habitat mapping. Progress in Physical Geography, 29, 449-474.

McKenzie, D., \& Halpern, C. B. (1999). Modeling the distributions of shrub species in Pacific Northwest forests. Forest Ecology and Management, 114, 293-307.

Morrison, M. L., \& Raphael, M. G. (1993). Modeling the dynamics of snags. Ecological Applications, 3, 322-330.

Murphy, M. A., Evans, J. S., \& Storfer. (in press). Quantifying Bufo bores connectivity in Yellowstone National Park with landscape genetics. Ecology.

Nelson, R., Keller, C., \& Ratnaswamy, M. (2005). Locating and estimating the extent of delmarva fox squirrel habitat using an airborne LiDAR profiler. Remote Sensing of Environment, 96, 292-301.

Nelson, R. F., Krabill, W. B., \& Tonelli, J. (1988). Estimating forest biomass and volume using airborne laser data. Remote Sensing of Environment, 24, 247-267.

Noss, R. F. (1999). Assessing and monitoring forest biodiversity: A suggested framework and indicators. Forest Ecology and Management, 115, 135-146.

Ohmann, J. L., McComb, W. C., \& Zunrawi, A. (1994). Snag abundance for primary cavity-nesting birds on nonfederal forest lands in Oregon and Washington. Wildlife Society Bulletin, 22, 607-620.

Pesonen, A., Maltamo, M., Eerikäinen, \& Packalen, P. (2008). Airborne laser scanningbased prediction of coarse woody debris volumes in a conservation area. Forest Ecology and Management, 255, 3288-3296.

Prasad, A. M., Iverson, L. R., \& Liaw, A. (2006). Newer classification and regression tree techniques: Bagging and random forests for ecological prediction. Ecosystems, 9, $181-199$.

Prosser, D. J., \& Brooks, R. P. (1998). A verified habitat suitability index for the Louisiana Waterthrush. Journal of Field Ecology, 69, 288-298.

R Development Core Team (2005). R: A language and environment for statistical computing. R Foundation for Statistical Computing, Vienna, Austria ISBN:3-90005107-0, URL http://www.R-project.org

Riaño, D., Meier, E., Allgöwer, B., Chuvieco, E., \& Ustin, S. L. (2003). Modelling airborne laser scanning data for the spatial generation of critical forest parameters in fire behaviour modelling. Remote Sensing of Environment, 86, 177-186.

Roloff, G. F. (2001). Habitat suitability model for dusky flycatcher (Empidonax oberholseri) in the intermountain West. Timberland Resources, Boise Cascade Corporation, Boise, ID 6 pp.

Ruiz-Gazen, A., \& Villa (2007). Storms prediction: Logistic regression vs. random forest for unbalanced data. Case studies in business, industry and government statistics, Vol. 1 . (pp. 91-101).

Russell, R. E., Saab, V. A., \& Dudley, J. (2007). Habitat suitability models for cavity-nesting birds in a postfire landscape. The Journal of Wildlife Management, 71, 2600-2611.

Sampson, R. N., \& Adams, D. L. (1994). Assessing forest ecosystem health in the inland west New York: Food Products Press $461 \mathrm{pp}$.

Schroeder, R. L. (1982). Habitat suitability index models: Downy woodpecker. US Department of the Interior, Fish and Wildlife Service FWS/OBS/82/10.38. 10 pp.

Scott, J. M., Peterson, C. R., Karl, J. W., Strand, E., Svancara, L. V., \& Wright, N. M. (2002). A GAP Analysis of Idaho: Final report. Idaho Cooperative Fish and Wildlife Research Unit. Moscow, ID, USA.

Skowronski, N., Clark, K., Nelson, R., Hom, J., \& Patterson, M. (2007). Remotely sensed measurements of forest structure and fuel loads in the Pinelands of New Jersey. Remote Sensing of Environment, 108, 123-129.

Souza, P. J. (1982). Habitat suitability index models: Lewis' woodpecker. US Department of the Interior, Fish and Wildlife Service, FWS/OBS/82/10.32. 14 pp.

Souza, P. J. (1987). Habitat suitability index models: Hairy woodpecker. US Department of the Interior, Fish and Wildlife ServiceBiol. Rep., Vol. 82 (10.146). 19 pp.

Spiering, D. J, \& Knight, R. L. (2005). Snag density and use by cavity-nesting birds in managed stands of the Black Hills National Forest. Forest Ecology and Management, $214,40-52$.

Stage, A. R. (1976). An expression of the effects of aspect, slope, and habitat type on tree growth. Forest Science, 22, 457-460. 
Stoker, J., Harding, D., \& Parrish, J. (2008). The need for a national lidar dataset. Photogrammetric Engineering and Remote Sensing, 74, 1066-1068.

Strobl, C., Boulesteix, A., Zeileis, A., \& Hothorn, T. (2007). Bias in random forest variable importance measures: Illustrations, sources and a solution. BMC Bioinformatics, 8, 25.

Su, J., \& Bork, E. W. (2007). Characterization of diverse plant communities in Aspen Parkland rangeland using LiDAR data. Applied Vegetation Science, 10, 407-416.

Sun, Y., Kamel, M. S., Wong, A. K. C., \& Wang, Y. (2007). Cost-sensitive boosting for classification of imbalanced data. Pattern Recognition, 40, 3358-3378.

Swatantran, A., Dubayah, R., Hofton, M., Blair, J. B., \& Handley, L. (2008). Mapping potential Ivory billed woodpecker habitat using LiDAR and hyperspectral data fusion. Eos, Transactions AGU, 89(53) 2008 Fall Meeting Suppl., Abstract B32A-04.

Thomas, J. W, Anderson, R. G., Maser, C., \& Bull, E. L. (1979). Snags. In J. W. Thomas (Ed.), Wildlife habitats in managed forests: The Blue Mountains of Oregon Washington. US Forest Service Agriculture Handbook, Vol. 553. (pp. 60-77) Washington, D.C., USA: Wildlife management Institute.

Turner, W., Spector, S., Gardiner, N., Fladeland, M., Sterling, E., \& Steininger, M. (2003). Remote sensing for biodiversity and conservation. Trends in Ecology and Evolution, 18, $306-314$.

Turner, M. G., Gardner, R. H., \& O'Neill (2001). Landscape ecology in theory and practice. New York: Springer.

Van Pelt, R., \& Franklin, J. F. (2000). Influence of canopy structure on the understory environment in tall, old-growth, coniferous forest. Canadian Journal of Forest Research, 30, 1231-1245.

Venier, L. A., \& Pearce, J. L. (2007). Boreal forest landbirds in relation to forest composition, structure, and landscape: Implications for forest management. Canadian Journal of Forest Research, 37, 1214-1226.
Vierling, K. T., Vierling, L. A., Martinuzzi, S., Gould, W., \& Clawges, R. (2008). Lidar: Shedding new light on habitat modeling. Frontiers in Ecology and the Environment, 6, 90-98.

Virkkala, R. (2006). Why study woodpeckers? The significance of woodpeckers in forest ecosystems. Annales Zoologici Fennici, 43, 82-85.

Wulder, M., \& Franklin, S. (2003). Remote sensing of forest environments: Concepts and case studies. Dordrecht / Boston / London: Kluwer Academic Publishers. 519 pp.

\section{Further reading}

Bolstad, P. V., \& Lillesand, T. M. (1992). Improved classification of forest vegetation in Northern Wisconsin through rule-based combination of soils, terrain, and Landsat TM data. Forest Science, 38, 5-20.

Evans, I. S. (1972). General geomorphometry, derivates of altitude, and descriptive statistics. In R. J. Chorley (Ed.), Spatial analysis in geomorphology (pp. 17-90). Now York, Karper \& Raw.

Moore, I. D., Gessler, P. E., Nielsen, G. A., \& Petersen, G. A. (1993). Terrain attributes: Estimation methods and scale effects. In A. J. Jakeman, M. B. Beck, \& M. McAleer (Eds.), Modeling change in environmental systems (pp. 189-214). London: Wiley.

Riley, S. J., DeGloria, S. D., \& Elliot, R. (1999). A terrain ruggedness index that quantifies topographic heterogeneity. Intermountain Journal of Science, 5, 1-4.

Tarboton, D. G. (1997). A new method for the determination of flow directions and contributing areas in grid digital elevation models. Water Resources Research, 33, 309-319. 